\title{
Teaching Transactional Skills in Partnership with the Bar
}

\author{
(C) Carl J. Circo, 2011*
}

Introduction. 187

I. What Does the Profession Want from Legal Education?

A. The Broad Outlines of the Profession's Interest in Practical Skills Training... 190

1. Observations from bar organizations and recent conferences

2. A few recent observations from practicing lawyers and law firms

B. What Does the Profession Want Law Schools to Do to Prepare Graduates for Transactional Practice?

1. A few comments from recent professional conferences ..........209

2. Empirical data from law firm professional development departments.

II. What Are Law Schools Currently Doing to Prepare Graduates for Transactional Practice?

III. The Promise of Educational Partnerships between Law Schools and the Bar

A. The Need for Empirical Data ....................................................232

B. The Need for Innovation and Experimentation..............................233

C. The Need for Collaboration between the Bar and Law Schools ...235

1. Alternative ways for practicing lawyers to teach law students

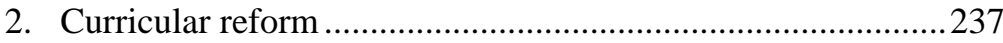

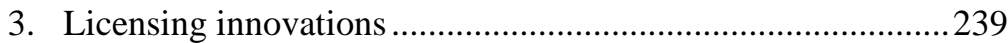

Final Thoughts 240

\section{INTRODUCTION}

With increasing emphasis, practicing lawyers call on law schools to provide more practical skills training. ${ }^{1}$ Lawyer development professionals add weight to

\footnotetext{
* Associate Dean and Arkansas Bar Foundation Professor of Law, University of Arkansas School of Law. The author acknowledges the helpful research assistance of Keawaii Crow, a 2012 graduate of the University of Arkansas School of Law, and expert technical assistance with footnotes by Meredith Hoberock, also a 2012 graduate of the University of Arkansas and Joshua Edwards, a second-year law student at the University of Arkansas.
} 
these demands. ${ }^{2}$ And the organized bar, particularly the American Bar Association, which accredits law schools, brings a sense of urgency to the cause. ${ }^{3}$ Many legal educators also promote practical skills training. ${ }^{4}$ But the practicing bar and the legal academy do not necessarily share common perspectives, or even a common language, about the need for reform in legal education. We need more dialogue that engages both sides.

We also need to broaden the discussion to encompass a wider range of practical skills. The scholarly and professional literature addressing why and how legal education should do a better job preparing law students for practice is more highly developed in addressing litigation and dispute resolution than business and transactional practice. ${ }^{5}$ This shortcoming reflects the strong advocacy bias in traditional legal education.

In light of these considerations, this Article explores the practical skills reform movement with two goals in mind. First, it seeks to articulate and reconcile some of the fundamental differences in the perspectives of the practicing bar and the legal academy. Second, it highlights the special challenges and opportunities involved in making legal education more practical for students who will practice transactional and business law. Parts I and II explore what practical skills the legal profession seeks from the academy and what initiatives law schools are proposing in response. Each discussion begins with a general overview, followed by a more extensive look at transactional skills. The ultimate question is whether these developments within the bar and the academy will converge for the mutual benefit of the legal profession and legal education. Part III proposes more creative partnerships between the bar and the academy to implement an effective and efficient transactional skills curriculum on a national basis.

\section{What DoEs THE PROFESSION WANT FROM LEGAL EDUCATION?}

This should be the easy part. For generations, practicing lawyers and judges have criticized legal education for failing to graduate students who have the

\footnotetext{
${ }^{1}$ They want more in two senses. Lawyers want skills training to be more practical, and they want law schools to offer more training in practical skills. See Harry T. Edwards, The Growing Disjunction Between Legal Education and the Legal Profession, 91 MicH. L. REV. 34 (1992); John Burwell Garvey \& Anne F. Zinkin, Making Law Students Client-Ready: A New Model in Legal Education, 1 DuKE F. FOR L. \& SOC. CHANGE 101 (2009).

2 See generally IdA O. AbBotT, LaWyers' Professional DeVelopment: The Legal Employer's COMPREHENSIVE GUIDE 9-11 (2002).

${ }^{3}$ See generally Austin G. ANDERSON \& SANDRA J. BOyer, THe EFFeCtive AsSOCIATE TRAINING AND Development PROgRam, A.B.A. STANDing Comm. on ContinUing Legal Educ. \& THE A.B.A. CENTER FOR CONTINUING LEGAL EDUC., 1-4, 75-78 (2d ed. 2005).

${ }^{4}$ See infra Part II.

${ }^{5}$ See Lisa Penland, What a Transactional Lawyer Needs to Know: Identifying and Implementing Competencies for Transactional Lawyers, 5 J. Ass’N LEGAL WRITING DIRECTORS 118, 120-22 (2008).
} 
Teaching Transactional Skills in Partnership with the Bar

skills they need to practice law. ${ }^{6}$ This is hardly surprising, because contemporary legal education stands as the victory of an academic scholarship model over a practical apprenticeship model. That battle was decisively waged during the late 19th and early 20th century. ${ }^{7}$ Ever since, a steady stream of lawyers, judges, bar organizations, and professional commissions have urged law schools to offer more practical training. And the recent criticisms have become more commonplace and, in some cases, harsher. ${ }^{8}$ Yet, the long and welldocumented history of the practical skills controversy offers a much more complete description of the perceived problems than of the potential solutions. What specific practical abilities does the profession want law schools to teach, and how should they do it?

This should be the easy part. But it is not.

No single formula answers these questions. Different bar organizations and lawyers offer many alternative perspectives on the goals of legal education. Moreover, as the discussion that follows shows, the organized bar frequently offers relatively general and abstract recommendations. Even assuming that the academy wishes to do more to prepare graduates for the practice of law-an assumption that many within and outside of law schools question-how should legal educators translate that commitment into curricular adjustments? ${ }^{9}$

Although professional voices fail to articulate a unitary reform program, they at least offer recurring refrains that suggest some directions. Most of the distinct themes complement one another, or at least they do not conflict, but a few strains seem contradictory. What is most challenging is that several of the key criticisms and proposals from the profession offer too little specificity to induce effective curricular and programmatic reforms. This can be frustrating for a law faculty and for individual professors. But the lack of detail may prove beneficial. To the extent that the current reform movement remains in its formative phase, broad ideas about objectives may be enough to stimulate the exper-

\footnotetext{
${ }^{6}$ Some recent articles recount the long history of the criticism. See Edwards, supra note 1, at 34-42; Brent E. Newton, Preaching What They Don't Practice: Why Law Faculties' Preoccupation with Impractical Scholarship and Devaluation of Practical Competencies Obstruct Reform in the Legal Academy, 62 S.C. L. REV. 105, 106, 108-11 (2010); Robert J. Rhee, On Legal Education and Reform: One View Formed from Diverse Perspectives, 70 MD. L. REV. 310, 313 (2011).

${ }^{7}$ See Erwin Chemerinsky, Why Not Clinical Education?, 16 CliniCAL L. Rev. 35, 37-40 (2009).

${ }^{8}$ See Lynne L. Dallas, Limited-Time Simulations in Business Law Classes, 45 J. LEgAL Educ. 487 (1995); Edwards, supra note 1, at 34-42; John Burwell Garvey \& Anne F. Zinkin, Making Law Students Client-Ready: A New Model in Legal Education, 1 DuKE F. FOR L. \& Soc. ChANGE 101 (2009); Newton, supra note 6, at 105; Rhee, supra note 6, at 331-33 (criticizing especially the third-year curriculum); Charles Fox, Getting up the Learning Curve: Five Thoughts on Training First-Year Transactional Lawyers, TRAnSACtional PRACTICE TODAY, Jan. 2011, available at http://www.foxprof.com/Articles /getting-up-the-learning-curve.aspx; David Van Zandt \& Michelle Greene, Stress Core Competencies, NAT’L L.J., July 7, 2008; Michael Woronoff, What Law Schools Should Teach Future Transactional Lawyers: Perspectives from Practice (UCLA School of Law, Law-Econ Research Paper No. 09-17, 2009), available at http://ssrn.com/abstract $=1430087$.

${ }^{9}$ See, e.g., William L. Reynolds, Back to the Future in Law Schools, 70 MD. L. REv. 451, 452-53 (2011); Newton, supra note 6, at 106-07.
} 
imentation that can foster discrete solutions.

\section{A. The Broad Outlines of the Profession's Interest in Practical Skills Training}

\section{Observations from bar organizations and recent conferences}

The American Bar Association's ongoing project to revise its standards governing accredited law schools provides a convenient point to launch this discussion. ${ }^{10}$ The ABA's Section of Legal Education and Admissions to the Bar (the Legal Education Section) promulgates the accreditation rules that govern U.S. law schools. ${ }^{11}$ The Legal Education Section began its current comprehensive review of its Standards and Rules of Procedure for Approval of Law Schools (the ABA Standards) more than three years ago. ${ }^{12}$

Chapter 3 of the ABA Standards directly addresses the need for practical skills education. ${ }^{13}$ The latest proposed version of ABA Standard 301 states a twofold objective of a law school's educational mission. ${ }^{14}$ The two components, while unquestionably practical in tone, give little concrete guidance. The draft calls for law schools to prepare students "for admission to the bar and for effective, ethical and responsible participation as members of the legal profession." ${ }^{\text {15 }}$ Proposed Standard 302 offers further guidance by placing these two broad objectives in the context of learning outcomes intended to give graduates the knowledge and skills required for entry-level practice. ${ }^{16}$ While the introduction of learning outcomes into law school accreditation standards might lead a school to adopt an effective skills curriculum, proposed Standard 302 falls short of assuring that result.

In particular, as presently expressed, the standards relating to practical skills are noticeably less specific and measurable than those relating to knowledge. With respect to knowledge, the draft provides that a law school's learning outcomes should call for students to attain entry-level competency in "substantive and procedural law."17 These are relatively well understood fields of study. Moreover, law school exams and the bar exam provide ways to

10 See Standards Review Committee, AMERICAN BAR AssociATION, http://www.americanbar.org/groups/legal_education/committees/standards_review.html l (last visited January 19, 2013).

${ }^{11}$ See A.B.A. Standards and Rules of Procedure for Approval of Law Schools, SEC. Of LEGAL EDUC. \& ADMISSIONS TO THE BAR (2012-2013) [hereinafter A.B.A. Standards].

${ }^{12}$ See Mark Hansen, Too Much Momentum?, A.B.A. J., May 2011, at 55.

${ }^{13}$ A.B.A. Standards, supra note 11 at $\S 301$.

14 Standards Review Committee, American BAR Association, supra note 10, at $\S 301$ (draft Jan. 14, 2013). This revised draft was released while this Article was in the final editing stage. The latest version addresses some of the criticisms leveled in the text by providing a clearer picture of how the standards may ultimately define practical skills training. See infra note 22.

${ }^{15} \mathrm{Id}$.

${ }^{16} \mathrm{Id}$. at $\S 302$.

${ }^{17} \mathrm{Id}$. at $\S$ 302(b)(1). 
Teaching Transactional Skills in Partnership with the Bar

measure how well a law school imparts knowledge of the law and procedure.

By contrast, in the skills category, the proposed standard barely goes beyond describing the threshold training objectives of a traditional, theoretical legal education. The skills identified include "legal analysis and reasoning, legal research" and "written and oral communication." 18 To those routine first-year learning objectives, the draft adds "problem solving." merely echoes the general language of Standard 301 by requiring that a school's learning outcomes include entry-level competency in "other professional skills needed for competent and ethical participation as a member of the legal profession." 20 The other elements of the proposed standard on learning outcomes concern ethics and professional values, along with other learning outcomes a particular school might choose to designate in accordance with its own circumstances and goals. ${ }^{21}$

Considered alone, a standard that requires law schools to teach students how to solve problems may suggest little more than the limited use of class time to discuss the same kind of hypothetical situations already common in conventional case books. The vague additional requirement for learning outcomes to include some level of competence in undefined "other professional skills needed" for practice cannot assure that law schools will effectively address the skills gap. In effect, the proposed ABA Standards leave most of the details about skills outcomes for each school to determine. Presumably, this tactic recognizes distinctions in the populations and missions of different law schools. ${ }^{22}$ As a matter of regulatory policy, this may be wise, but by design it leaves open the most important decisions about curricular reform. ${ }^{23}$

Aside from the ABA's formal position on accreditation under the ABA Standards, many other segments of the profession have advanced suggestions to improve practical skills training in law school. What follows is a review of

${ }^{18} I d$. at $\S 302(\mathrm{~b})(2)$.

${ }^{19} \mathrm{Id}$.

${ }^{20} I d$. at $\S 302(\mathrm{~b})(4)$.

${ }^{21} I d$. at $\S 302(\mathrm{~b})(3) \&(5)$.

${ }^{22}$ The final element of the learning outcomes standards reflects this policy. It calls for "other learning outcomes deemed by the school as important or necessary to meet the needs of its students and to accomplish its mission." Id. at § 302(b)(5). A proposed interpretation would clarify that "other professional skills" include: "interviewing; counseling; negotiation; fact development and analysis; trial practice; document drafting; conflict resolution; organization and management of legal work; collaboration; cultural competency; and self-evaluation.” Id. at Interpretation 302-1. Another proposed standard, while it adds no further information about the specific skills to be taught, provides for a potentially important requirement for every student to complete "one or more experiential course(s)," meaning "(i) simulation course(s); or (ii) in-house clinical course(s); or (iii) field placement(s).” Id. at § 303(a)(3). These proposed additions to the standards could resolve some of the deficiencies noted in the text.

${ }^{23}$ Cf. Larry Kramer, Remarks at the NALP Future of Lawyer Hiring Roundtable 37-38 (Sept. 28, 2009), available at http://www.nalp.org/uploads/0909TRANSCRIPT_web.pdf. Kramer enthusiastically noted the creative potential for experimentation in the legal academy today but criticized the ABA for overregulating law schools and thereby restricting what law schools can do to respond to the demand for more practice-ready graduates. Id. 
some of the most prominent and recent reports and commentary.

One especially useful example comes from the ABA's Real Property, Trust and Estate Law Section, which recently formed a Task Force on Real Property Law Curricula. ${ }^{24}$ The Task Force issued a report roundly criticizing the trend among law schools to reduce the credit hours devoted to the first-year Property course and to de-emphasize fundamental real estate aspects of property law covered during that first year course. ${ }^{25}$ The task force's initial report stems from a review of published law school curricula and a survey of property law professors. ${ }^{26}$ Following those studies, the task force surveyed young lawyers engaged in real estate practices. ${ }^{27}$

Because the task force focused on substantive law coverage, it did not make recommendations directly concerning practical skills training. But the work of the task force confirms that practicing lawyers believe that legal education does not adequately prepare law students for practice, at least in the context of real estate law. That perception shows in the findings and recommendations of the task force composed of seasoned practitioners. ${ }^{28}$ It also resounds in the responses of the relatively inexperienced lawyers who participated in the second survey. ${ }^{29}$ The new real estate lawyers also expressed a preference for the law school property curriculum, including upper-level courses, to provide more practical training on transactional aspects. ${ }^{30}$ Beyond that, the task force undertook a more limited survey of a small group of experienced real estate practitioners, and that survey further supports the view that, at least for purposes of commercial real estate work, law school does not adequately equip law students for practice. ${ }^{31}$

Other leading organizations in the legal community also have contributed significantly to the skills gap dialogue. One of the most useful of these is the NALP Foundation roundtable conference series, which was conducted during six meetings over a two-year period. ${ }^{32}$ The series focused broadly on lawyer hiring and development. While much of the attention during these sessions was

\footnotetext{
${ }^{24}$ See Roger Bernhardt \& Joanne Martin, Teaching the Basic Property Course in U.S. Law Schools, Prob. \& Prop., Sept./Oct. 2007, at 36, available at http://www.kybar.org/documents/inside_kba /sections /realprop/sec15_proj_2.pdf.

${ }^{25}$ Id. at 37, 40-41; Joanne Martin, The Nature of the Property Curriculum in ABA-Approved Schools and Its Place in Real Estate Practice, 44 ReAl Prop. ProB. \& TR. J. 385, 425 (2009).

${ }^{26}$ See Martin, supra note 25, at 389-93.

${ }^{27}$ Id. at $412-24$.

${ }^{28}$ See Bernhardt \& Martin, supra note 24, at 36, 40-42.

${ }^{29}$ See Martin, supra note 25, at 424.

${ }^{30}$ See id. at 421, 424.

${ }^{31}$ See id. at $413-14$.

${ }^{32}$ The Future of Lawyer Hiring, Development \& Advancement Roundtable Series, NAT'L Ass'N FOR LAW PLACEMENT [hereinafter NALP Roundtable Series], available at http://www.nalp.org /futureoflawyerhiring. The meetings were held on June 24, 2009, September 19, 2009, December 14, 2009, March 12, 2010, April 11, 2011, and June 8, 2011. Id.
} 
Teaching Transactional Skills in Partnership with the Bar

on lawyer recruiting and training at large law firms, several sessions also dedicated significant time to legal education in general. Taken as a whole, the NALP Foundation series paints a helpful picture of the current dissatisfaction within the profession over legal education.

The dominant theme in the NALP conferences reflects a client's perspective on the value that competent lawyers bring to legal work. Sophisticated clients often conclude that new law school graduates have little to offer because they lack meaningful practice experience. ${ }^{33}$ On this consideration, participants in the first roundtable session in the NALP Foundation series discussed how experiential learning and practical skills training in law school might make new lawyers more practice-ready. ${ }^{34}$

In a particularly telling exchange during this initial session, law firm and law school participants explored the attributes that new lawyers should possess to be ready for practice. ${ }^{35}$ They distinguished between two contrasting skill types. One category involves the relatively broad abilities that successful lawyers and their clients commonly associate with valuable legal work across a wide range of circumstances. ${ }^{36}$ The other involves technical skills tied to distinct legal activities, the relevance of which varies from one practice field or situation to another. ${ }^{37}$ The first category includes the foundational skills that a traditional legal education teaches most effectively, such as legal research and analysis, legal writing, and advocacy. But it also extends to other extremely important abilities that law schools have conventionally slighted, such as problem solving, project management, teamwork, risk assessment, and emotional intelligence. ${ }^{38}$ Think of all of these abilities as general competencies. The second category involves narrower skills tied to specialty practices, such as the ability to depose an expert witness or to conduct due diligence for a business acquisition. Think of these as technical competencies. In some discussions, many of the abilities here called general competencies-in particular those that law schools traditionally do not teach-are characterized as soft skills. ${ }^{39}$ At least according to some of the roundtable participants, the core deficiency of legal education is its failure to cover a more comprehensive range of general competence rather than its lack of courses designed to teach technical compe-

${ }^{33}$ See Excerpts from the Transcript, A Roundtable on the Future of Lawyer Hiring, Development and Advancement, NATL'L Ass'N FOR LEgAL CAREER PROF'L 10-12 (Jun. 24, 2009), http://www.nalp.org/uploads/ documents/RoundtableExcerpts0723.pdf [hereinafter NALP Excerpts].

${ }^{34} I d$. at $18-21$.

${ }^{35} \mathrm{Id}$. at 21-24.

${ }^{36}$ See, e.g., id. at 24-25.

${ }^{37}$ See, e.g., id. at 19-21.

${ }^{38}$ See NALP Excerpts, supra note 33, at 19-20. The ultimate general competence is judgment, an attribute commonly attributed almost entirely to experience rather than to education.

${ }^{39}$ See id. Others use different terms to distinguish the two concepts. See, e.g., HeAtHer BocK \& RoBert Ruyak, CONSTRUCTING CORE COMPETENCIES: Using COMPETENCY MODELS TO MANAGE FIRM TALENT 13-14 (2006) (using the terms "behavioral competencies" and “technical competencies"). 
tence. ${ }^{40}$

Another theme developed during the first of these roundtable discussions is that there are significant opportunities for the bar and law schools to collaborate to improve legal education. ${ }^{41}$ The most common versions of this kind of collaboration include practicing lawyers who serve as adjunct faculty teaching practical skills or who are guest speakers in courses taught by fulltime faculty. ${ }^{42}$ Law schools also invite practicing lawyers to participate in special practice forums or focus groups. ${ }^{43}$ Some law schools sponsor programs that match students with lawyers who volunteer to work on pro bono projects. ${ }^{44}$ Many schools ask alumni and local practicing attorneys to serve on advisory councils. $^{45}$

At some sessions during the series of meetings, conference participants also discussed prospects for lawyers to take on students as apprentices on some basis that allows students to gain practice experience working on real client matters under the supervision of experienced lawyers. ${ }^{46}$ The apprenticeship model can substantially reduce the costs that fulltime associates create for law firms or their clients. Established systems in several other countries offer alternative models for integrating apprenticeship programs into legal education and lawyer licensing. ${ }^{47}$ Note, however, that once an apprenticeship scheme becomes part of the licensing process, it may become an independent post-J.D. program rather than a collaborative effort between law schools and the practicing bar. ${ }^{48}$

The NALP series also devoted considerable attention to competency models that law firms use to train and assess new lawyers. ${ }^{49}$ Many large firms have

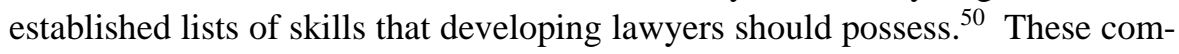
petency models typically distinguish between the characteristics of lawyers through different stages of their professional development, beginning with en-

${ }^{40}$ See NALP Excerpts, supra note 33, at 19-20.

${ }^{41} \mathrm{Id}$. at $24-30$.

${ }^{42} \mathrm{Id}$.

${ }^{43} I d$.

${ }^{44} \mathrm{Id}$.

${ }^{45}$ Id. See Transcript, A Roundtable on the Future of Lawyer Hiring, Development and Advancement, NAT'L ASS'N FOR LEGAL CAREER PROF'L 20 (Dec. 14, 2009), http://www.nalp.org/uploads /RoundtableTranscript_12_14_09.pdf [hereinafter NALP Transcript].

${ }^{46}$ See id. at 17-20.

${ }^{47}$ The Canadian articling system is one good example that received considerable attention at the NALP conference. See id.

${ }^{48}$ This point is especially recognized in the discussion of apprenticeships at the second installment of the NALP series. See Transcript, A Roundtable on the Future of Lawyer Hiring, Development and Advancement, NAT'L AsS'N FOR LEGAL CAREER PROF'L 33 (Sept. 28, 2009), http://www.nalp.org /uploads/0909TRANSCRIPT_web.pdf [hereinafter Sept. NALP Transcript].

${ }^{49}$ Transcript, A Roundtable on the Future of Lawyer Hiring, Development and Advancement, NAT'L Ass'N FOR LEGAL CAREER PROF'L 26 (Sep. 28, 2009), http://www.nalp.org/uploads /0909TRANSCRIPT_web.pdf [hereinafter Dec. NALP Transcript].

${ }^{50} I d$. at 40 . 
Teaching Transactional Skills in Partnership with the Bar

try-level abilities. ${ }^{51}$ As a result, it is possible to distill from these professional development tools some relatively well-defined principles about the most important expectations that these firms have for new lawyers. ${ }^{52}$ What we can learn from law firm competency models is discussed in greater detail below. ${ }^{53}$

The third session in the NALP series began with a rather blunt assessment of whether law schools were finally getting the message that both the practicing bar and clients expect graduating law students to have more practical skills than traditional legal education has managed to deliver. ${ }^{54}$ At least in some corners of the academy, the attitude is extant that practical skills can wait until after graduation. ${ }^{55}$ Starting from this observation, the discussion during the third NALP session quickly moved to the theme that, at a minimum, law schools could do a much better job teaching the problem-solving, teamwork, and risk assessment skills that practicing lawyers and sophisticated clients often claim that law graduates lack-general competencies. ${ }^{56}$ There was also considerable consensus among the participants that it is more important for law schools to focus on these general competencies than on the technical ones. ${ }^{57}$ One lawyer described the primary objective of practical skills training as teaching those competencies that are transferrable from one specialty or practice setting to another, which is a different goal from teaching the technical expertise required within a particular legal discipline. ${ }^{58}$ This same session returned to the issue of how law schools and the bar could collaborate to make practical skills development more feasible in legal education, but the participants did not propose any significant innovations over existing strategies. ${ }^{59}$

The most recent NALP session in this series offered a retrospective both concerning ongoing changes in the profession and on the reform movement in legal education. ${ }^{60}$ Law school participants in the discussion consistently re-

${ }^{51} I d$.

${ }^{52}$ See Transcript, A Roundtable on the Future of Lawyer Hiring, Development and Advancement, NAT'L ASS'N FOR LEGAL CAREER PROF'L 16-17 (Mar. 12, 2010) [hereinafter Mar. NALP Transcript]; see also Transcript, A Roundtable on the Future of Lawyer Hiring, Development and Advancement, NAT'L Ass'N FOR LEGAL CAREER PROF'L 19-20 (Apr. 11, 2011), http://www.nalp.org/uploads/documents/ April11RoundtableFinalTranscript0419.pdf [hereinafter Apr. NALP Transcript]. Both the March 12, 2010 and the April 11, 2011 roundtable conferences suggest that as more law firms adopt competency models, law schools should have clearer ideas of what entry-level skills firms require.

${ }^{53}$ See infra, notes $71-73 \& 112-140$ and accompanying text.

${ }^{54}$ NALP Transcript, supra note 45 , at 5-10.

${ }^{55}$ See, e.g., William M Sullivan et al., Educating LaWyers: Preparation For the Profession OF LAW 87-93 (2007) (noting that the prevailing attitude at many law schools continues to favor teaching legal analysis over practical skills).

${ }^{56}$ NALP Transcript, supra note 45, at 2-11. Those participating in this session reinforced the distinction between so-called soft and hard skills, and they generally agreed that law schools should add soft skills, such as emotional intelligence, to the skills curriculum. See id. at 2-15.

${ }^{57} \mathrm{Id}$.

${ }^{58} \mathrm{Id}$. at 18

${ }^{59}$ Id. at $16-17,20-24$.

${ }^{60}$ Apr. NALP Transcript, supra note 52, at 2-10. 
ported an increased commitment to experiential learning, in the form of liveclient clinics, externships, skills simulation courses, and pro bono opportunities. ${ }^{61}$ A NALP Foundation survey of law firm associates provided some relevant empirical data for the discussion. ${ }^{62}$ The developing lawyers who participated in the survey placed a high value on the practical benefits of clinics and externships, but gave much lower evaluations to law school skills courses and pro bono experiences. ${ }^{63}$

Another recent conference presents the views of a particularly broad spectrum of the legal community. The American Law Institute-American Bar Association CLE venture and the Association for Continuing Legal Education jointly sponsored a 2009 Critical Issues Summit. ${ }^{64}$ In addition to representatives of the two organizing entities, the conference planning committee included members from state CLE commissions, state bars, the judiciary, many leading law firms, legal publishers, legal consulting firms, the Professional Development Consortium, the National Association for Law Placement, the Practicing Law Institute; and the conferees at the summit and the program's contributing sponsors represent an even wider circle. ${ }^{65}$ The conference advocated a continuum of legal education and professional development for lawyers that includes law school, the bar admission process, mandatory CLE, and inhouse law firm training. ${ }^{66}$

The conference's main work product is a list of sixteen concise recommendations, accompanied by equally concise commentary on selected aspects of the recommendations. ${ }^{67}$ Several of the suggestions seek to influence the reform movement in legal education. In language that channels the proposed ABA Standards, Recommendation 1 proposes that law schools take steps to define, implement, and regularly assess learning outcomes "to ensure that their graduates are capable of serving as effective beginning lawyers."68 The reporter's comment explains that while the recommendation respects differences in law school approaches, it promotes practical education by "placing a high value” on

${ }^{61} \mathrm{Id}$. at $10-18$.

622010 Survey of Law School Experiential Learning Opportunities and Benefits, NAT’L Ass'N FOR LEGAL CAREER PROF'L (May 2011), http://www.nalp.org/may2011research_exp_learning.

${ }^{63}$ Respondents gave the following very useful ratings: legal clinics, $63.1 \%$; externships, $60.1 \%$; skills courses, 38.5\%; pro bono work, $17 \%$. Id. at 26. In the NALP conference series, several speakers noted that in the technical skills arena for large law firms, trial advocacy (the leading skills course in law schools by enrollment) is the least relevant, and others added that negotiating ability, alternative dispute resolution skills, and legal writing and drafting expertise are much more important for new lawyers in that environment. NALP Roundtable Series, supra note 32, at 16-17 (Apr. 11, 2011).

${ }^{64}$ See Equipping our Lawyers: Law School Education, Continuing Legal Education, and Legal Practice in the $21^{\text {st }}$ Century, ALI-ABA COMM. ON CONTINUING PROF'L EDUC. \& THE Ass'N FOR CONTINUING LEGAL EDUC., 2010 [hereinafter EQUIPPING OUR LAWYERS].

${ }^{65}$ See id. at X-xxiv.

${ }^{66} I d$. at 5 .

${ }^{67}$ Id. at 6-12.

${ }^{68}$ Id. at 6 . 
Teaching Transactional Skills in Partnership with the Bar

the responsibility of law schools for "preparing their students for legal careers." 69 Other recommendations call for extensive cooperation and partnerships between law schools, bar examiners, bar organizations, the bench, practicing lawyers, and CLE providers to achieve a more integrated, career-long process of lawyer professional development. ${ }^{70}$

On the whole, the report demonstrates extraordinary support for the use of core competency models throughout the professional development continuum. Recommendation 2, for example, proposes that law schools provide a beginning point for the continuum by integrating "core practice competencies" into learning outcomes. ${ }^{71}$ Another recommendation is that law schools should refine their competency lists "by stage of education and by practice area."72 Another portion of the report advocates a collaborative effort to research and test core practice competency models and to align those models with curricula for post-J.D. professional development. ${ }^{73}$

The report also endorses an expanded role for experiential education in law schools. ${ }^{74}$ But it does not project onto law schools the exclusive responsibility for the envisioned professional development continuum, nor does it imply that law schools can or should perform the most important functions for assuring practical competence. Rather, the report calls for highly developed and administered transitional programs for new lawyers in the form of "post-admission apprenticeships" and mandatory "universal mentoring requirements for new admittees." 75 In this sense, the Critical Issues Summit reserves its most radical and controversial reform proposals for the bar admissions and mandatory CLE realms.

Yet another industry perspective comes from a National Institute for Trial Advocacy (NITA) whitepaper issued in 2009. ${ }^{76}$ In comparison to the discussions and reports covered above, which consider a broad spectrum of professional development concerns in the legal profession, the NITA white paper primarily targets the practical skills gap that exists when new law school graduates enter the practice. ${ }^{77}$ Although, as indicated by the organization's name, NITA is especially dedicated to litigation skills, the paper looks broadly at training for the entire legal profession. The NITA white paper considers a wide range of practice specialties and, like the ALI-ABA report, it envisions a con-

${ }^{69}$ EQUIPPING OUR LAWYERS, supra note 64, at 6.

${ }^{70}$ See id. at 6-8, 10 (Recommendations 2, 4, and 11).

${ }^{71} \mathrm{Id}$. at 6-7.

${ }^{72}$ See id. at 7 (Recommendation 3).

${ }^{73}$ See id. at 10-11 (Recommendations 11 and 12).

${ }^{74}$ See EQUIPPING OUR LAWYERS, supra note 64, at 7 (Recommendation 4).

${ }^{75}$ See id. at 8 (Recommendation 4).

${ }^{76}$ The Future of Legal Education: A Skills Continuum, NAT'L INST. FOR TRIAL AdVOCACY, 2009 [hereinafter NITA].

${ }^{77}$ See id. at 1-2, 5-6. 
tinuum of skills training that includes law schools, on-the-job professional development, and continuing legal education. ${ }^{78}$

Several aspects of the NITA white paper reflect some of the most common themes sounded by contemporary discussions of practical skills training for lawyers, many of which have already been mentioned above. In this respect, the paper confirms the significance of many of the same factors highlighted by the NALP Foundation series. A background statement argues that recent economic and client-based changes in the market for legal services mandate a permanent commitment to practical skills in legal education and throughout a legal career. $^{79}$

The paper's overview offers a short list of practical skills not effectively taught in law school. Consistent with other recent studies and commentary, NITA's catalogue of the practice essentials emphasizes overarching professional skills more than discrete technical skills associated with specific practice areas. This distinction reinforces the educational preference for general competencies over technical ones. Except for the first item specified in the list, the critical "real-world skills" that NITA finds lacking in new lawyers are equally absent from the objectives of traditional legal education. While the list does not purport to identify all areas of concern for a skills agenda, it promotes a surprising shift in educational priorities by highlighting a handful of topics that would seem odd to most law school curriculum committees (again with the exception of the first one), but utterly familiar to nearly any business or service enterprise:

Ethics and professionalism

Business acumen

Leadership and management

Client service and relations

Financial/economic analysis; and

Business development. ${ }^{80}$

Following this overview, the NITA white paper gives more concrete advice that largely coincides with the most significant recommendations that other recent investigations have advanced. Law schools should rely more heavily on experiential learning opportunities, and they should look for opportunities to collaborate more with practicing lawyers, the organized bar, and CLE providers. ${ }^{81}$ Law professors should reduce reliance on lectures, reading assignments, and demonstrations in favor of the learn-by-doing approach that characterizes

\footnotetext{
${ }^{78}$ See id. at 3-4.

${ }^{79} \mathrm{Id}$. at $1-4$

${ }^{80} \mathrm{Id}$. at 6 .

${ }^{81}$ See id. at 8, 24, 30-31.
} 
Teaching Transactional Skills in Partnership with the Bar

NITA's long-standing strategy for teaching litigation skills. ${ }^{82}$ To implement the learn-by-doing technique, business school style case studies should frequently supplant the conventional appellate case method. ${ }^{83}$

The NITA analysis extends well beyond a law school education, arguing forcefully that the practical skills gap demands significant reform efforts by the practicing bar and licensing authorities. ${ }^{84}$ It endorses post-J.D. apprenticeships ${ }^{85}$ advocates highly structured lawyer competency models as essential to the development of the technical expertise required for practice specialties, ${ }^{86}$ and encourages law firms to implement highly structured professional development and work allocation programs ${ }^{87}$ and to use secondments to send their new lawyers out to work temporarily with clients. ${ }^{88}$

The final recommendation, which NITA accurately characterizes as its "most far-reaching and simultaneously least tangible" goal, calls on all of the relevant institutions to collaborate to establish "a national Standard of Practice for U.S. attorneys." 89 The paper makes no attempt to elaborate this notion beyond explaining that, as a matter of licensing or ongoing CLE, uniform standards of practice should identify and address those "skills and experiences of value to clients." 90 This tantalizing proposal suggests that the CLE consultants and lawyer professional development experts who contributed to the NITA white paper may expect to close the skills gap by pressing the practicing bar, the licensing authorities, and providers of post-J.D. training toward radical change more than by urging law schools to implement extensive reform. And to stress the point, the paper concludes with an appeal for bar examiners, bar associations, law firms, and CLE providers to join with law schools in an ambitious collaborative effort to change the future direction of the legal education continuum. ${ }^{91}$

The compatibility of NITA's recommendations with those of the NALP roundtable series and the Critical Issues Summit should comfort anyone hoping to discover common threads in the now palpable enthusiasm that the legal profession demonstrates for serious and widespread educational reform. In ad-

${ }^{82}$ See id. at 11-12. NITA has long followed this formula for teaching trial advocacy skills. See, e.g., DAVID M. MALONE ET AL., THE EFFECTIVE DePOSITION: TECHNIQUES AND STRATEGIES THAT WORK 24 (3d ed. 2007).

${ }^{83}$ MALONE ET AL., supra note 82, at 24.

${ }^{84}$ See id. at 12-22, 27-30.

${ }^{85} \mathrm{Id}$. at 8 .

${ }^{86} I d$. at 9 .

${ }^{87}$ Id. at $9,12-22$.

${ }^{88} \mathrm{Id}$. at 22-23; A secondment is a temporary work assignment in which an attorney is sent to another department or firm to gain experience. See, e.g. АвBотT, supra note 2, at 149; see also, The Oxford English Dictionary 830 (R.W. Burchfield ed. 2nd ed. 1989).

${ }^{89} \mathrm{Id}$. at 30.

${ }^{90} \mathrm{Id}$.

${ }^{91}$ See id. at 31. 
dressing designated skills, these conferences repeatedly emphasized those that are transferrable across specialties, such as problem solving and teamwork. ${ }^{92}$ And they consistently support the view that deficiencies in skills of this nature account for much of the gap between what a traditional legal education provides and what most entry-level legal practices require. ${ }^{93}$ In summary, one particularly compelling point emerges: the most important skills that new lawyers need are not technical competencies that accomplished lawyers use in representing clients expertly in particular legal contexts, such as business litigation or transactions, or for specific client settings, such as general business, technology, intellectual property, real estate, domestic relations, or estate planning. Rather, the essential skills of practice-ready lawyers are dominantly those that are transferrable across multiple practice contexts—general competencies.

\section{A few recent observations from practicing lawyers and law firms}

Generations of judges and practicing lawyers have lamented the failure of law schools to add more practical skills training to the legal theory, topical knowledge, and analytic thinking of a traditional legal education. ${ }^{94}$ Some of these complaints are legendary and influential. ${ }^{95}$ Others may be apocryphal. Both the rise of lawyer training programs in major law firms and the bottomline urgency induced by the recent recession have encouraged practicing lawyers, their firms, and professional development departments to produce a body of written work that reinforces and supplements the profession's perspectives on legal skills described above. Recounting the criticisms and recommendations at length would enflame more than enlighten the current discussion. But a brief review of a few recent examples will help complete the picture of the skills gap as perceived in professional circles. ${ }^{96}$

Suggestions from a lawyer who participated in a recent symposium on legal education catalog some common proposals. ${ }^{97}$ He urges law schools to increase the use of practicing lawyers, judges, and clients as adjunct professors and

\footnotetext{
${ }^{92}$ See, e.g., EQUIPPING OUR LAWYERS, supra note 64, at 6-12; Apr. NALP Transcript, supra note 52, at 43-45.

${ }^{93} \mathrm{Id}$.

${ }^{94}$ See generally Newton, supra note 6, at 106, 108-13; Woronoff, supra note 8, at 2.

${ }^{95}$ Prominent judges frequently complain that legal scholarship contributes little to the practical concerns of the bench. See Newton, supra note 6, at 114-20 (recounting some of the recent judicial criticism).

${ }_{96}^{96}$ An extremely important contrast, which the introduction to this Article briefly notes, appears by means of this review. The conferences, studies, and reports from the institutional bar paint a useful landscape, but by reason of their expansive nature they offer little detailed advice on the specific steps that law schools might take to close the skills gap. Materials from practicing lawyers, on the other hand, tend to be much more focused on particular practice contexts and, as a result, they offer more definitive, but limited, direction.

${ }^{97}$ Neil J. Dilloff, The Changing Cultures and Economics of Large Law Firm Practice and Their Impact on Legal Education, 70 MD. L. REV. 341, 359-63 (2011).
} 
Teaching Transactional Skills in Partnership with the Bar

guest speakers. ${ }^{98}$ Additionally, he calls for the law school curriculum to incorporate more opportunities for students to observe legal proceedings, negotiations, and meetings, and to include apprenticeship programs, work-study internships, simulations, demonstrations, and clinics. ${ }^{99}$

Another practicing lawyer, with many years of experience teaching as a law school adjunct professor, argues that law schools fail to produce more practiceready lawyers primarily because so few full-time law professors have significant experience practicing law. ${ }^{100}$ As a result, he would begin legal education reform by radically changing the composition of law faculties rather than by merely bringing in more practicing attorneys as adjuncts and guest speakers. ${ }^{101}$ In addition to restructuring law faculties, he advocates increased reliance on clinics and other experiential programs. ${ }^{102}$

Not all practitioners who have contributed to the current debate over legal education reform argue for the primacy of skills training. For example, one lawyer concludes that law schools generally should concentrate their limited resources on teaching law students more substantive knowledge of the law because that is what schools do best and it is what beginning lawyers need most. ${ }^{103}$ He would leave the development of expertise to law firms, which are better equipped than law schools for that purpose because law firms have the necessary experts and the time required for true expertise to germinate. ${ }^{104}$ Law schools should, however, do a better job teaching certain practical skills, such as contract drafting and negotiating techniques, as well as helping students acquire some critical general competencies, such as business acumen. ${ }^{105}$ But because he believes that law students need extensive substantive knowledge, too much emphasis on practical skills training during law school could lead to the inefficient use of the limited time available for formal legal education. ${ }^{106}$

As noted, much of the recently published commentary emanates from large law firms and the lawyer professional development community that serves those firms. As a result, the balance of this subsection samples the perspective of large national firms, which comprise one important, but minority, segment of the practicing bar. While these firms occupy an especially visible position in the practical skills gap dialogue, as discussed more fully in Part III of this Article, any comprehensive assessment of the deficiencies in legal education re-

${ }^{98} I d$. at 360, 362-63.

${ }^{99} \mathrm{Id}$. at 360-62.

${ }^{100}$ Newton, supra note 6, at 107-08.

${ }^{101}$ Id. at $148-51$.

${ }^{102}$ Id. at $140-47$.

${ }^{103}$ Woronoff, supra note 8, at 5-9.

${ }^{104} \mathrm{Id}$. at 9-13.

${ }^{105} \mathrm{Id}$. at $13-17$.

${ }^{106}$ Id. at $17-18$. 
quires data from across the spectrum of practicing lawyers.

In the world of elite law firms, the movement toward competency models is one of the most prominent reforms in current lawyer professional development literature. ${ }^{107}$ The business community has relied on competency models of employee development for years. ${ }^{108}$ Law firms have adopted the concept in large numbers only recently. ${ }^{109}$ In this context, competency models often have at least as much to do with associate compensation systems in large law firms as they do with helping new lawyers develop practical skills. ${ }^{110}$ But law firm competency models are highly relevant to the skills gap problem because they derive from the thoughtful articulation of the practical abilities that the firms expect new lawyers to develop as they progress from entry level work to highvalue expertise. Numerous resources, including several discussed elsewhere in this Article, document the growing interest in competency models. ${ }^{111}$ Brief reviews of two relatively recent books on the topic suffice for current purposes.

One of the seminal resources on the use of competency models for law firm professional development purposes was first published by Peter Sloan in 2002 and is now in its second edition. ${ }^{112}$ Although Sloan's account emphasizes how a competency model can improve a law firm's associate assessment and compensation systems, it also illustrates how a law firm can integrate its training program into its competency model. ${ }^{113}$ By reflecting on the components of law firm competency models, law schools can learn much about what expectations partners in large law firms have of entry-level associates, and also what deficiencies those partners perceive in a traditional legal education. Rather than differentiate competencies for specific practice specialties, Sloan's approach advocates identifying general competencies applicable to all practices within the firm. ${ }^{114}$

Sloan's model groups competencies into four broad categories: "professional competencies, work ethic, interpersonal skills, and client relations."115 Each category includes from three to seven specific performance abilities. Out of the entire competency list, only four are standard law school learning objectives. All four fall under the professional competencies category. They are: written communication; oral communication; research and analytical ability;

\footnotetext{
${ }^{107}$ A competency model measures an attorney's skills, behavior, and attitude for career development. Competencies include areas beyond knowledge of the law. See Аввотт, supra note 2, at 45, 189-190, 194-195.

${ }^{108}$ BOCK \& RUYAK, supra note 39, at 3

${ }^{109}$ Аввотт, supra note 2, at 190.

${ }^{110} \mathrm{Id}$.

${ }^{111}$ See Dec. NALP Transcript, supra note 49, at 7.

112 Peter B. SLOAN, From Classes to Competencies, LocKSTEP to LEVELS (2007).

${ }^{113} \mathrm{Id}$. at 23-24.

${ }^{114} \mathrm{Id}$. at 20 .

${ }^{115} \mathrm{Id}$.
} 
Teaching Transactional Skills in Partnership with the Bar

and professional ethics. ${ }^{116}$ Creativity and flexibility, judgment, and crisis management complete the list of professional competencies. The work ethic group includes efficiency and effectiveness, timeliness, and initiative, ambition, and drive. The interpersonal skills are teamwork and cooperation with the firm, tact and diplomacy, and delegation and supervision. Finally, the client relations group consists of client relations, client management, and business development activities. ${ }^{117}$

Law schools probably cannot systematically teach some of the most general of these abilities, such as efficiency and effectiveness; initiative, ambition, and drive; or tact and diplomacy. Many skills courses, however, could at least alert students to the potential importance of these lawyerly qualities and could offer problems, exercises, or demonstrations that illustrate how these attributes fit into selected practice contexts. ${ }^{118}$ A few other competencies on this list, such as client management, might be too dependent on a particular firm culture or practice setting for any meaningful treatment in law school. Most of the specified competencies, however, are so central to what lawyers working in many different practice specialties must learn to do in connection with certain commonplace services that they could at least be addressed at an introductory level through many law school skills programs.

Of course, very few of these skills can be developed at high performance levels during law school, but that is entirely beside the point. The essential functions of a law firm competency model are first to identify the key abilities that successful lawyers must have and then to articulate useable descriptions of how a lawyer should manifest those abilities at different stages of professional development, beginning with entry level and progressing incrementally as the lawyer gains experience. ${ }^{119}$ In the large law firm setting, the logical course is to tie these performance descriptions to compensation levels by differentiating each competency within each compensation level. And a firm that links the assessment and compensation systems with a structured professional development program should offer training sessions and work assignment opportunities that allow its associates to learn and improve in each of these areas in ways that facilitate and encourage progress from one competency level to another. Thus emerges the educational application of a law firm competency model.

A good way to illustrate both how such a competency system should work

${ }^{116} I d$.

${ }^{117} \mathrm{Id}$.

${ }^{118}$ A negotiations skills course, for example, offers many opportunities for students to learn about efficiency, initiative, tact, and diplomacy in a problem-solving context. See CHARLES B. CRAVER, EFFECTIVE LEGAL NEGOTIATION AND SETTLEMENT 1-7 ( $7^{\text {th }}$ ed. 2012). And simulation courses can help students develop many of the general skills that are most important for transactional lawyers. See Robert C. Illig, Teaching Transactional Skills Through Simulations in Upper-Level Courses: Three Exemplars, 2009 TRANSACTIONS: TENN. J. BUS. L. 15 (2009).

${ }^{119}$ See SLOAN, supra note 112, at 20-22. 
and what a model may say about the skills gap in legal education is to analyze the descriptions of an illustrative competency category from entry level through the higher proficiency levels. The ideal competencies to use for this purpose involve skills that law schools already teach, but that practicing lawyers still frequently mention when they talk about the skills gap. Even a casual review of recurring criticisms from the bench, bar, and professional development literature discloses that written communication is an excellent candidate for this exercise. ${ }^{120}$

In most law firm competency models, the first level of a competency describes the attributes that the firm expects of new graduates. Sloan's model gives this description of level 1 , or entry level, competence in written communication: "Drafts clear and concise correspondence, pleadings, legal memoranda, or transactional documents, for review by supervising lawyer." ${ }^{121}$ Note that the description omits any reference to the substantive quality of the writing, which is presumably left to the senior lawyer's review. At higher levels, proficiency advances as the developing attorney's work product should be appropriate "for review by supervising lawyer and requiring few modifications" (level 2), to the stage in which the lawyer becomes "primarily responsible" for most written work "with minimal review by supervising lawyer" (level 3), until, at the final level covered by the model, the lawyer assumes "supervisory responsibility over other lawyers working on less complex matters."122

From a law school perspective, this model sets a modest target for entrylevel competence in writing. The level 1 standard merely anticipates written work product acceptable for review by a supervising lawyer; it does not require the newly admitted lawyer to produce documents that are ready to send to clients or file with courts or other public offices, nor does it ask beginning lawyers to submit documents suitable to submit to opposing counsel or lawyers on the other side of a transaction. In one important sense, this expectation is far below what writing programs and courses in most law schools should logically establish for themselves, because most schools must not only prepare some graduates to work under the close and constant supervision of more experienced lawyers but also train those who will begin to practice immediately upon being admitted to the bar, with little or no ongoing supervision.

The purpose of examining this single competency description for written communication is simply to demonstrate that at least some of the skills that law

\footnotetext{
${ }^{120}$ See, e.g., Tina L. Stark, Training Junior Transactional Associates-Third and Fourth Years, 17 ALIABA INSIDER No. 2 at 1 (Summer 2003). In the professional development literature, the criticism concerning written communication skills is sometimes implicit rather than explicit, but powerful nonetheless. See, e.g., CAROlyn E. C. PARIS, Drafting FOR CoRporate Finance: What LaW School DOESN'T TEACH YOU passim (2007)

${ }^{121}$ SLOAN, supra note 112, at 21.

${ }^{122} \mathrm{Id}$.
} 
Teaching Transactional Skills in Partnership with the Bar

firms identify as core competencies can be linked pedagogically to a law school curriculum and to conceivable learning outcomes. Whether or not the legal education system, as a whole, or a specific law school or course in particular, should adopt that pedagogic approach is addressed further in Part III. For present purpose, it is enough to conclude the analysis by merely noting a few other level 1 competencies in the model that Sloan describes. In each instance, it is relatively easy to imagine how law school courses, especially experiential ones, could be developed to teach these capabilities to the proficiency level indicated.

The entry level competence of creativity and flexibility reads: "Able to identify and articulate alternative courses of action and strategies for consideration by the supervising lawyer. Adapts and deals with changed situations quickly." ${ }^{\prime 23}$ Could not a simulation for a dispute resolution course be designed with just such a learning outcome in mind? For teamwork and cooperation with firm, the level 1 description is "Willing to work effectively with others to address client and firm needs. Interacts well with staff and other lawyers."124 According to several commentators, many law school courses could include assignments that inculcate basic teamwork habits by having groups of students work cooperatively on case studies much in the same way that business schools do. ${ }^{125}$ Even the competency for judgment - that gold star quality found almost exclusively in highly experienced lawyers - anticipates a relatively attainable expression in the entry-level lawyer: "Able to identify risks involved in alternative courses of action." ${ }^{126}$ In short, there is no reason to conclude that law students could not, over the course of three years, benefit from experiences carefully designed, presented, and assessed, for the purpose of helping them to develop many of the practical skills that at least this one competency model contemplates for beginning lawyers.

A 2006 competency guide published by the American Bar Association helps round out the large law firm perspective on entry-level expectations. ${ }^{127}$ This book is based on a model that was developed by the now defunct global litigation firm, Howrey LLP. ${ }^{128}$ It touts the use of a competency model primarily as a law firm management device rather than a skills training system. But the Howrey model is no less useful for purposes of understanding how a

\footnotetext{
${ }^{123} I d$. at app. B, B1.

${ }^{124}$ Id. at B3.

${ }^{125}$ See, e.g., Tina L. Stark, Thinking Like a Deal Lawyer, 54 J. LEgAL EduC. 223 (2004).

${ }^{126} I d$. at B2.

${ }^{127}$ See generally BOCK \& RUYAK, supra note 39.

${ }^{128}$ See id. at 1-11. The firm's failure does not, at least in any obvious sense, seem to relate to its competency model for associates, although it may call into question the firm's management ideas in general. See Steven Pearlstein, Why Howrey Law Firm Could Not Hold It Together, WASH. PosT., Mar. 19, 2011, http://www.washingtonpost.com/business/economy/why-howrey-law-firm-could-not-hold-it-toget her/2011/03/16/ABNTqkx_story.html (attributing the failure to overly ambitious expansion, and characterizing the firm's competency-based associate compensation system as innovative).
} 
lawyer competency scheme might help a law school establish learning outcomes for experiential courses.

One especially helpful contribution of the book is the construct of "foundational competencies," depicted as a pyramid divided into two major segments, one labeled "Behavioral Competencies (Soft Skills)" at the base of the structure, and the other labeled "Technical Competencies (Hard Skills)" forming the topic sections of the pyramid. ${ }^{129}$ Three categories of behavioral competencies together provide the broad foundation upon which the technical competencies rest. ${ }^{130}$ Competencies relating to motives are at the base (such as "drive for excellence”), upon which rest the other two behavioral competencies categories, which are characterized as traits (such as "understanding others") and social role (such as "leadership"). ${ }^{131}$ Two technical competency segments build on the behavioral ones; the first is "Knowledge" (such as "Knowledge of Discovery Rules") and, at the top of the pyramid, "Skills" (such as "Oral Advocacy"). ${ }^{132}$ Once again, therefore, appears the distinction between general competencies and technical competencies.

The pyramid analogy provides a framework reflecting the proposition that any organization that manages human talent can tailor a competency model to serve its mission. ${ }^{133}$ It also evinces the belief that the truly foundational competencies for a commercial enterprise are not technical competencies but general competencies (behavioral skills) that do not necessarily vary much from one business or profession to another. ${ }^{134}$ "We see the same behavioral competencies or skill sets coming up again and again-competencies like leadership, teamwork, impact and influence, customer service orientation, the drive for excellence, and self growth.”135 From this perspective, only technical competencies - those at the top of the pyramid—relate primarily to the specific business activity or profession involved. And technical competencies, while essential for expertise, are ineffectual unless they are built on a foundation of general competencies (behavioral skills).

The Howrey model addresses litigator development under four major categories: "Building a Case for the Client," "Advocating for the Client," "Working with Others," and "Positioning Self and Firm for Success."136 Each of these categories divides into four competency topics, which include skills under relatively broad general (behavioral) and technical skill fields such as research, dis-

\footnotetext{
${ }^{129}$ BOCK \& RUYAK, supra note 39, at 13-14.

${ }^{130} \mathrm{Id}$. at 13

${ }^{131} \mathrm{Id}$.

${ }^{132} \mathrm{Id}$.

${ }^{133}$ See id. at 1-11 (expressly making this point).

${ }^{134} \mathrm{Id}$. at 14 .

${ }^{135}$ Id. (attributing the quoted statement to Lori Berman, an outside consultant the firm used to develop its competency model).

${ }^{136}$ Id. at $14-15$.
} 
Teaching Transactional Skills in Partnership with the Bar

covery, legal knowledge, written and oral communication, leadership, teamwork, and client service. ${ }^{137}$ As a final step in this scheme, the firm articulates a list of more specific competencies for each field. ${ }^{138}$

The "Factual Development and Investigation Competency" field illustrates a three-level performance ability scheme for this technical skill. ${ }^{139}$ Level 1 , captioned "Preparation and Support" lists seven expectations in this area for an entry-level associate relating to the ability "to collect, develop, and organize documents and other information in a coherent fashion" for litigation purposes. ${ }^{140}$ Several of the seven items require a degree of self-sufficiency in the beginning attorney in connection with elementary tasks. ${ }^{141}$ In summary form, these expectations contemplate an entry-level lawyer who "uses all available sources of information," who understands the importance of facts in a litigation setting, who "effectively and accurately reviews documents for privilege and relevance," who can prepare appropriate discovery documents, and who "elicits information about sources of facts, witnesses, data, and documents." 142 Beyond these abilities, the new lawyer also assists others in preparing for interviews and depositions and the testimony of witnesses.

Notice that these specifications merely anticipate law school graduates who understand the discovery process sufficiently to provide efficient and effective support for senior lawyers. Under this model, entry-level associates do not independently manage the discovery process, take depositions, or prepare witnesses. ${ }^{143}$ These competencies only appear in the level 2 list. ${ }^{144}$ This highlights one of the limitations inherent in assessing a law school curriculum solely on the basis of the needs of large law firms with elite practices. A law school pretrial skills program that fails to train students to assume full responsibility for discovery, including taking depositions and preparing witnesses, could not claim to produce graduates who are ready to practice in the typical small town setting or in many small- or mid-sized firms or in the offices of most prosecutors, public defenders, legal aid organizations, or government agencies. This is not to say that law schools should ignore the most readily available core competency models simply because they primarily emanate from firms large enough to have structured professional development programs. Rather, it may mean that law schools seeking to base learning outcomes on practical competencies should consider developing separate tracks, not only for dis-

\footnotetext{
${ }^{137} \mathrm{Id}$.

${ }^{138}$ Id. at $16-19$.

${ }^{139} \mathrm{Id}$. at $16-17$.

${ }^{140} I d$. at 16 .

${ }^{141} I d$.

${ }^{142} \mathrm{Id}$.

${ }^{143}$ Id. at $16-17$.

${ }^{144} \mathrm{Id}$.
} 
tinct practice fields, such as litigation and transactions, but also for different categories of prospective employers. And it may be in this particular detail of differentiation that one of the most troubling devils abides for the architects of legal education reform.

To sum up, these two examples of law firm competency models show that it is possible to articulate both the foundational attributes and the lawyering skills that law school graduates need to develop in order to succeed as entrylevel lawyers. They also suggest that, at least for some purposes and to some extent, law school faculties and law professors could construct curricula and courses to achieve learning outcomes that correspond to designated entry-level abilities. Assuming that faculties and professors want to adopt this course of action, they will need to collect and analyze much more data than the literature currently assembles. Because this Article seeks primarily to imagine a feasible and effective transactional skills curriculum, the next section asks what transactional lawyers are saying about the entry-level skills.

\section{B. What Does the Profession Want Law Schools to Do to Prepare Graduates for Transactional Practice?}

To large segments of the practicing bar, law school seems barely relevant to transactional work. Indeed, many transactional lawyers condemn the upperlevel curriculum as practically useless. The anecdotal evidence of these negative views oozes from overheard conversations in the halls of law firms and professional conferences. Unfortunately, formal studies, conference materials, and the published literature from the transactional bar do not adequately document the extent and bases for these opinions.

Indeed, in the past, much of the skills gap discussion within the profession has either not differentiated between practice areas or has primarily considered litigation and other dispute resolution topics. ${ }^{145}$ The contemporary conversation often continues this practice of considering the issue broadly, without consistently distinguishing between transactional skills and other practical skills. ${ }^{146}$ The transactional bar is, however, beginning to participate in the dialogue, as the discussion that follows shows. The next two sections consider the message being sent by the transactional bar in recent conferences and publications (section 1) and via preliminary empirical data on transactional skills training that the author collected from law firm professional development departments (section 2).

\footnotetext{
${ }^{145}$ See, e.g., Newton, supra note 6; Rhee, supra note 6.

${ }^{146}$ See, e.g., Dilloff, supra note 97, at 358-63.
} 
Teaching Transactional Skills in Partnership with the Bar

\section{A few comments from recent professional conferences}

To begin, whether or not considered expressly in a transactional context, the key skills that account for recurring themes in the general professional development literature and recent conference papers and reports apply at least as much to transactional work as to any other areas of practice. This is especially true for general competencies discussed in Part I.A. Every lawyer must communicate effectively both in writing and orally, and every lawyer needs to learn how to service clients and to exercise sound judgment and bring emotional intelligence to bear in the practice of law. And some of the attributes that most commonly appear in general competency skills lists are typically even more important in working with transactions and business matters than in dispute resolution. Consider, for example, the degree to which entry-level transactional lawyers will benefit from business acumen and from skills in teamwork, problem solving, project management, risk assessment, and financial analysis.

Although comprehensive discussions of the transactional skills gap are rare in the practice literature, some reports and commentators focus on skills in discrete transactional practice fields. For example, the report of the ABA's Real Property, Trusts and Estate's Law Section, discussed in Part I.A.1, levels special criticism at one transactional deficiency in particular. It urges greater attention to real estate transactions in first-year Property courses, to include purchase and sale contracts, deeds and conveyances, and real estate finance. ${ }^{147}$ Related surveys and interviews involving seasoned practitioners and young lawyers further support the conclusion that many practicing real estate lawyers concur that law schools should devote more time and resources to teaching transactional skills. ${ }^{148}$

The NALP Foundation roundtable series, also discussed in Part I.A.1, discloses similar perspectives from practicing lawyers about the transactional skills gap in general. ${ }^{149}$ One exchange in that series, for example, notes the value to entry-level transactional lawyers from being able to work with accounting concepts and reports. ${ }^{150}$

One transactional lawyer, who has teaching experience as an adjunct law professor, has recently offered a strategy that may surprise advocates of practical skills training. ${ }^{151}$ He urges law schools first to teach more substantive law, both because that is what law schools do best and because he believes that fu-

\footnotetext{
${ }^{147}$ See Bernhardt \& Martin, supra note 24, at 40-42. As discussed previously, this report deals almost exclusively with the substantive law coverage in the first-year Property course. See supra notes 24-31 and accompanying text. As a result, the discussion of practical skills is tangential.

${ }^{148}$ See Martin, supra note 25, at 413-14, 421.

${ }^{149}$ See supra notes 32-63 and accompanying text.

${ }^{150}$ Mar. NALP Transcript, supra note 52, at 23. The most direct comment on this point in the exchange, however, came from an academic participant. Id.

${ }^{151}$ See Woronoff, supra note 8.
} 
ture transactional lawyers need a broad knowledge base before they begin to practice. ${ }^{152}$ He derides as naive the suggestion that law schools could ever graduate students who have expertise in the sense that a transactional practice requires. ${ }^{153}$ For these reasons, he concludes that law schools should resist the temptation to integrate practical skills or business case studies into substantive law courses or otherwise to take time away from substantive law coverage. ${ }^{154}$ Rather, he prefers optional laboratory style courses, taught by practicing lawyers, as add-ons to substantive courses. ${ }^{155}$ He also endorses courses that teach the fundamental practical skills of contract drafting and transactional negotiations. ${ }^{156}$ Finally, he recommends more courses, beginning in the first year and continuing in the upper-level curriculum, to help students develop a sense for deals by teaching basic principles of accounting, finance, business, and economics. ${ }^{157}$ He concludes that many law students who are interested in transactional practice are nevertheless ill-prepared because they do not receive proper guidance and, as a result, do not take all of the classes they need. ${ }^{158}$

Specific transactional departments or practice groups in law firms often develop graduated skills or experience lists for their associates from which one can glean a notion of the skills that the firms expect the associates either to have or to be able to develop at the beginning of their careers. ${ }^{159}$ One firm's "Skill Set" list for real estate associates provides an example. ${ }^{160}$ The list reveals that entry level associates will prepare initial drafts of leases, contracts, and real estate loan documents for review by more experienced lawyers. ${ }^{161}$ This suggests not only the need for some law school training in transactional drafting, but also an interest in law school courses that help students develop an appreciation of the context in which real estate transactions take place. The new real estate lawyers also undertake more specialized tasks, such as title and survey review. ${ }^{162}$ The skill set list also indicates that the firm's real estate department presumes that law students either will not have or need not have negotiations training. Entry-level lawyers in the department provide support for more experienced lawyers in "most all aspects of a routine real estate loan transaction excluding negotiations.”163

\footnotetext{
${ }^{152} I d$. at 5-9.

${ }^{153}$ Id. at 9-13.

${ }^{154} \mathrm{Id}$. at $13-17$.

${ }^{155} \mathrm{Id}$. at 17.

${ }^{156} \mathrm{Id}$, at 13

${ }^{157} \mathrm{Id}$. at 17 .

${ }^{158} \mathrm{Id}$. at 18.

${ }^{159}$ See Аввотт, supra note 2, at 137-39, 239.

${ }^{160}$ See SLOAN, supra note 112, at D7-D9.

${ }^{161} \mathrm{Id}$.

${ }^{162}$ Id. at D7-D8.

${ }^{163} \mathrm{Id}$. at D7.
} 
Teaching Transactional Skills in Partnership with the Bar

The NITA white paper discussed in Part I.A.1 devotes one section to transactional skills training. ${ }^{164}$ In a non-exhaustive list of examples of experiential training in transactional skills, the paper mentions legal opinion negotiation, drafting and negotiating contracts, and transactional due diligence. ${ }^{165}$

The absence of an extensive body of professional literature specifically addressing what transactional skills entry-level lawyers need illustrates that there is insufficient information on the problem. The survey results discussed next may help fill part of that void.

\section{Empirical data from law firm professional development departments}

During July and August, 2011, the Author surveyed the opinions of law firm training and development professionals about the skills that entry-level transactional lawyers need. The study was made possible through the cooperation of the Professional Development Consortium (the PDC) and with the thoughtful assistance of Jennifer Bluestein, who is the Director of Attorney Professional Development for Greenberg Traurig, LLP and the PDC's Chair for 2011. The PDC, founded in 1990, serves to advance training and professional development for lawyers. Its members are law firm professional development directors and managers and others who work in lawyer professional development and recruiting. ${ }^{166}$

The survey instrument consisted of fifteen topical sections, some in multiple parts. ${ }^{167}$ The first six substantive sections asked about the skills that entrylevel lawyers usually have and the skills that entry-level transactional lawyers need. To a sobering (if not surprising) degree, the responses confirm the perception that significant segments of the profession find law school graduates to be only moderately prepared for practice, and especially for transactional work.

How well does law school prepare law students for practice? Not even a single respondent answered very well to that question, and only $7.4 \%$ responded well. When asked how well law school prepares entry-level litigation lawyers, legal education fared a bit better, with $3.7 \%$ responding very well and another $27.8 \%$ well. One can infer from these answers that many PDC members believe that law school does a much poorer job preparing students for transactional practice than for litigation. And that, indeed, is the picture the survey re-

\footnotetext{
${ }^{164}$ See NITA, supra note 76 , at 24-26.

${ }^{165} \mathrm{Id}$. at 26.

166 See Professional DeVelopment Consortium, http://www.pdclegal.org/ (last visited Mar. 6, 2012).

${ }^{167}$ The survey was distributed to 396 PDC members, and 55 submitted responses. The survey's empirical significance is limited both because of the relatively small number of participants and because the survey was not constructed or administered with a view toward rigorous social science standards. Statistical implications aside, the responses portray an important perspective of a significant number of professionals in law firm training and professional development. The survey results are on file with the author.
} 
sults paint. When asked how well law school prepares for entry-level transactional work, no one selected very well, and a scant $1.9 \%$ answered well.

When one takes into account those who think that law school at least adequately prepares students for practice, the results are less devastating. According to $63 \%$ of the respondents, law school satisfies that lower standard, and the percentage increases to over $84 \%$ when the question is limited to litigation practice. But less than $41 \%$ think that law school at least adequately prepares students for entry-level transactional practice, while almost 52\% answered poorly and $7.4 \%$ answered very poorly to that question. ${ }^{168}$ If the answers to these few questions alone even roughly approximate the opinions of the practicing bar, U.S. law schools appear to be seriously deficient in teaching practical skills for transactional work. ${ }^{169}$

The next section of the survey listed 25 skills often mentioned in discussions of the skills gap. ${ }^{170}$ These skills were derived from the same literature reviewed throughout this Article. They range from those traditionally claimed by legal education (legal analysis, legal research, and writing), to those that are distinctly practical yet relatively common in law school curricula and pedagogic literature (including interviewing, negotiating, and problem solving), to those more frequently mentioned by practicing lawyers and clients than by law professors (such as teamwork, emotional intelligence, financial analysis, and risk analysis), to those that have a distinctly academic tenor (interdisciplinary knowledge, global perspectives, and cultural competence).

The overwhelming collective opinion of the respondents is that law schools should teach most of these twenty-five skills to aspiring transactional lawyers. Only six items on the list garnered less than 60\% support (strongly agree or agree), and even those found support among around half of the respondents. The six at the bottom of the preference list, and the percentage of respondents who either strongly agreed or agreed with the statement that they were important for entry-level transactional lawyers are: interdisciplinary knowledge (56\%); global perspectives (55.1\%); leadership (54\%); self-evaluation (50\%);

\footnotetext{
${ }^{168}$ When the question was how well law school prepares students for practice in the respondent's own firm, the responses yielded the blended results one would expect from professional development directors whose firms generally engage both in litigation and transactions. More than $65 \%$ responded either well or adequately, while more than $31 \%$ answered poorly.

${ }^{169}$ For reasons discussed later, anyone considering the survey should recognize that the results do not necessarily reflect the judgment of the practicing bar as a whole.

${ }^{170}$ These are the listed skills, with the percentages of respondents who answered that they agreed or strongly agreed that law schools should teach them to prepare entry-level transactional lawyers: legal analysis and reasoning (98\%); legal research (94\%); problem solving (92\%); written communication (92\%); oral communication (94\%); interviewing (69.4\%); counseling (75.5\%); negotiating (81.6\%); fact development and analysis (90\%); conflict resolution (78\%); exercise of professional judgment (84\%); organization and management of legal work (80\%); teamwork (80\%); client relations (68\%); cultural competency (46\%); self-evaluation (50\%); leadership (54\%); global perspectives (55.1\%); financial analysis (74\%); risk analysis (80\%); business management (64\%); project management (82\%); managing others (48\%); emotional intelligence (70\%); and interdisciplinary knowledge (56\%).
} 
Teaching Transactional Skills in Partnership with the Bar

managing others (48\%); and cultural competence (46\%). The responses in this section of the survey imply that many in lawyer professional development believe that law schools should continue to teach all of the skills they already teach and should add others. There is no hint that these lawyer development professionals doubt the importance of the primary learning objectives of traditional legal education. ${ }^{171}$ This section of the survey deliberately omitted any inquiry into the relative importance assigned to one skill over another or any consideration of which skills should be given priority in light of the limited time and scarce resources available to law schools.

The next section of the survey explored the priority and allocation of resources issues. It identified eight targeted transactional skills and, with respect to each, asked whether the respondents agreed with the statement that, to prepare students for entry-level transactional work, "law schools should reduce the attention devoted to substantive law courses if necessary in order to devote more attention to teaching" the specified transactional skill. The responses indicate a substantial preference for significant reallocations in favor of transactional skills that are either not taught explicitly in many schools or that are offered only on a limited basis. These are the eight skills and the corresponding percentages of respondents who either strongly agreed or agreed that law schools should devote more attention to them, even if doing so requires reduced attention to substantive law courses:

Contract structures and key elements of $\quad 85.7 \%$ contracts common in many transactions

Common deal structures

$85.5 \%$

Financial analysis

$75 \%$

Due diligence in business transactions

$69.4 \%$

Business acumen

$69.4 \%$

Transactional negotiations

$67.3 \%$

Drafting documents for specific trans$63.3 \%$ actions (such as mergers and acquisitions, corporate finance, commercial

${ }^{171}$ In narrative comments, a few of the respondents explicitly stated that law schools do about as much as they can be reasonably expected to do. 
lending, or real estate)

Negotiating the terms of specific trans$51 \%$ actions (such as mergers and acquisitions, corporate finance, commercial lending, or real estate)

The transactional skills on the list that received the highest percentage of strongly agree responses for priority reallocation of resources were: contract structure and key elements of contracts common in many transactions (46.9\%); common deal structures (42.8\%); and business acumen (40.8\%). And, as the table above shows, after adding the agree responses to those in the strongly agree category, the data show overwhelming preference for sacrificing some substantive law coverage to make room to teach each of these general competencies for transactional lawyers. ${ }^{172}$ Only due diligence in business transactions was disfavored for the purposes stated by significantly more that $10 \%$ of the respondents. Just over $12 \%$ - still a remarkably small proportion-would not reduce attention to substantive law courses in favor of due diligence training. Note that, in contrast to the other most highly prized skills on the list, the ability to conduct due diligence may be characterized as a technical competency rather than a general one. That distinction might explain why a slightly greater minority of respondents would not sacrifice substantive law coverage to teach due diligence skills. The same consideration may explain why drafting and negotiating for specific transactions were favored by the smallest majorities.

Another section of the survey asked about the recent and future commitments of law firms to train entry-level lawyers. Many discussions of the attitudes of clients and law firms toward paying for associate training in the current economic downturn strongly suggest that firms have reduced their commitments to training, and will likely cut training even further in the future. ${ }^{173}$ Those participating in the survey depart from the conventional wisdom on these subjects. Almost 56\% disagree or strongly disagree with the claim that firms have become less willing to provide entry-level training over the past five years. And just over $60 \%$ disagree or strongly disagree with the prediction

\footnotetext{
${ }^{172}$ Some might categorize one or more of these skills as technical rather than general. But, to the extent that a general competency for a transaction lawyer is a transferrable ability needed in most distinct transactional specialty practices, the abilities involved are rightfully treated as general competencies.

${ }^{173}$ See, e.g., Daniel B. Bogart, The Right Way to Teach Transactional Lawyers: Commercial Leasing and the Forgotten "Dirt Lawyer", 62 U. PITT. L. REV. 335 (2000); see also, NALP Excerpts, supra note 33, at 10; Van Zandt \& Greene, supra note 8; Transcript, A Roundtable on the Future of Lawyer Hiring, Development, and Advancement, NAT'L Assoc. FOR Legal CAREER PROF'LS (June 24, 2009), http://www.nalp.org/june24futureoflawyerhiringroundtable; JoAnne D. Ganek, Successful Development

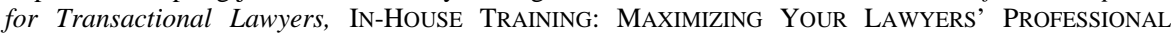
Potential 165-184 (ALI-ABA Course of Study, Feb. 18, 1994).
} 
Teaching Transactional Skills in Partnership with the Bar

that firms will become less willing to provide entry-level training during the coming five years. Because the respondents were all professionals committed to lawyer training and development, their views on this question may have been colored by optimism attributable to their own plans and hopes for their firms.

The survey participants generally believe that transactional lawyers must learn some aspects of their trade by doing. Almost $60 \%$ of them agreed or strongly agreed with this statement: "Entry-level lawyers cannot adequately be prepared to engage in a transactional practice until they have had experience working on deals under the supervision of experienced transactional lawyers." Only $28.6 \%$ disagreed with that statement, and none strongly disagreed.

These opinions about the critical role of actual practice do not, however, mean that the respondents discount the efficacy of experiential education during law school for preparing students for transactional practice. Another survey section asked the participants to assess the effectiveness of 12 categories of experiential learning techniques, from law school clinics, to judicial externships, to externships and clerkships in law firms, to pro bono projects. Over $50 \%$ of the respondents answered that all but two of these techniques are either highly effective or effective. ${ }^{174}$ In keeping with the prevailing judgment that some transactional skills can only be developed through actual practice, these lawyer development professionals most valued experiences that are typically available only after students complete their formal education. Over $95 \%$ believe that "practice experience supervised by more senior attorneys" is either highly effective (76.2\%) or effective (19\%). Running closely behind is the relatively rare and controversial category of "law school externships with law firms" at $92.9 \% .{ }^{175}$ "In-house law firm or legal department training programs" and "temporary placements with client organizations (secondments)" tied at an impressive $90.5 \% .{ }^{176}$ The devices that were relatively less valued turn out to be ones most favored by many contemporary law schools that tout their experien-

\footnotetext{
${ }^{174}$ The techniques and percentages of responses in the highly effective and effective categories are: law school live-client clinics (78\%); law school externships with judges (20.9\%); law school externships with for-profit organizations (83.3\%); law school externships with not-for-profit organizations (61.9\%); law school externships with law firms (92.9\%); law school simulation courses (83.3\%); summer associate programs in law firms and other organizations (85.7\%); clerkships with law firms and other organizations (other than summer associate programs) (81\%); in-house law firm or legal department training programs (90.5\%); pro bono work supervised by law school faculty (50\%); pro bono work supervised by a practicing attorney (57.2\%); practice experience supervised by more senior attorneys (95.2\%); and temporary placements with client organizations (secondments) (90.5\%).

${ }^{175}$ See Carl J. Circo, An Educational Partnership Model for Establishing, Structuring, and Implementing a Successful Corporate Counsel Externship, 17 CLINICAL L. REV. 99, 114-16, 121-22 (2010) (discussing concerns legal educations have expressed about externship placements with for profit organizations). In the private firm externship category, $40.5 \%$ of the respondents selected highly effective, and $52.4 \%$ selected effective.

${ }^{176} 40.5 \%$ of respondents rated in-house law firm or legal department training programs highly effective and $50 \%$ rated these programs as effective. $52.4 \%$ of respondents rated temporary placements with client organizations (secondments) as highly effective and $38.1 \%$ rated these placements as effective. Id.
} 
tial learning programs. ${ }^{177}$ "Externships with judges" received the endorsement of only $20.9 \%$. This may simply recognize that judicial externships generally do not expose students at all to transactional skills. Pro bono projects were also less favored than the other experiential learning techniques, but they still received respectable assessments. Pro bono work supervised by practicing lawyers fared somewhat better (57.2\%) than that supervised by faculty members (50\%).

Several survey questions called for narrative answers or invited supplemental comments. For a few of these questions, as many as half of the participants responded, but on most topics there is too much variation among the responses to support any general conclusions. Some themes appear in the narratives, however, that are consistent with some of the most common shortfalls that transactional lawyers regularly note about legal education. First, students graduate from law school without a sufficient understanding of business contracts, especially how and why contracts are structured in particular ways. Also, law school graduates generally have inadequate contract drafting skills. Additionally, law schools do not give enough attention to business and financial literacy. Finally, too many entry-level transactional lawyers have no feel or sense for business deals.

What do the survey results mean for the legal education reform movement? In the first place, they show the need for much more empirical data before law schools, the bar, and regulators can reliably assess the practical skills gap for transactional work. This survey involved a relatively narrow and specialized segment of consumers of legal education. Almost all of the respondents were professionals devoting most of their time to lawyer training and professional development in relatively large law firms. ${ }^{178}$ This survey helps to fill a data void in the contemporary literature, but only in a limited context. Researchers must gather similar information from a much larger and more diverse group of firms and practicing lawyers and other consumers of legal education.

Despite these limitations, the survey results justify some tentative observations. Law firm professional development departments have grown in significance and status to the point that those who direct and staff them certainly must reflect the judgments of many lawyers in private practice, especially those in large firms. ${ }^{179}$ And while data collected exclusively from one segment of the practice should be regarded with due caution, law schools that ignore this evidence that standard law school programs and curricula may be seriously defective do so at considerable risk. And this is especially true when these some-

${ }^{177}$ See Circo, supra note 175, at 102 (noting the prevalence of judicial and pro bono externships in law school programs).

${ }^{178}$ More than $46 \%$ of the respondents work in law firms that employ over 550 lawyers, and approximately $95 \%$ of them work in firms that employ at least 100 lawyers.

${ }^{179}$ See BoCK \& RUYAK, supra note 39, at 2-8. 
Teaching Transactional Skills in Partnership with the Bar

times harsh judgments are considered along with the other significant criticisms discussed in this Article.

Altogether, the soundings from the practicing bar more than hint at a crisis for a legal education system that chooses to remain aloof from the profession that it trains and that regulates it. The logical next question is whether law schools are heeding the warning that law graduates are not well-prepared for transactional work in the contemporary marketplace.

\section{What ARE LAW SCHOOLS CURRENTLy DOING TO PREPARE GRADUATES FOR TRANSACTIONAL PRACTICE?}

Spurred on especially by the two prominent national reports on legal education issued in 2007, the legal academy has been devoting much time and energy to the skills gap. ${ }^{180}$ The ABA's proposed learning outcomes standards also highlight demand for practical skills training. ${ }^{181}$ Additional fuel comes from many of the other forces that have inspired the professional conferences and reports discussed in Part I. In fact, these external pressures have engendered a body of academic resources that is far too extensive for comprehensive coverage in an article of this scope. ${ }^{182}$

What follows in this Part, therefore, is a highly selective review of the current academic discourse relevant to transactional skills education. The literature, conferences, educational programs, and ideas considered here fall into two broad categories. Those in the first group are among the most recent and farreaching, chosen because they provide a contemporary snapshot of the academic reform landscape. The others recount curricular developments that more directly concern skills training for transactional practice. Taken together, these resources epitomize the major reform ideas currently percolating through the law school community that will influence whether and how law schools might retool to produce graduates who are more prepared for transactional practice.

In reflecting on these developments this Part raises two central questions.

${ }^{180}$ See Roy StUCKey ET AL., BeSt PRACTICES FOR LEgAL EdUCATION (2007); SUlLiVAN ET AL., supra note 55.

${ }^{181}$ See supra notes $10-23$ and accompanying text.

182 The idea that law schools should teach practical skills is not new; rather, it has simply undergone transformation and renewal in the past few years. Legal education in the United States progressed from an apprenticeship model in the $19^{\text {th }}$ Century, in which aspiring lawyers read law in the offices of established lawyers, to the gradual triumph of formal graduate education, which occurred during the late $19^{\text {th }}$ and early $20^{\text {th }}$ Century, with an emphasis on teaching practical skills only gaining support in the later years of the $20^{\text {th }}$ Century. See generally SulLIVAN ET AL., supra note 55; Robert E. Matthews, Negotiation: A Pedagogical Challenge, 6 J. LEG. EDUC. 93 (1953-1954); Denton R. Moore \& Jerry Tomlinson, The Use of Simulated Negotiation to Teach Substantive Law, 21 J. LEG. EDUC. 579 (1968-1969); Robert S. Redmount, The Transactional Emphasis in Legal Education, 26 J. LEG. EDUC. 253 (1974); Debra Pogrund Stark, See Jane Graduate: Why Can't Jane Negotiate a Business Transaction?, 73 ST. JoHN's L. REV. 477 (1999); Bryn Vaaler, Bridging the Gap: Legal Opinions as an Introduction to Business Lawyering, 61 UMKC L. REV. 23 (1992); Report of the Task Force on Law Schools and the Legal Profession: Narrowing the Gap, 1992 A.B.A. SEC. L. EDUC. AND ADMISSIONS TO THE BAR. 
First, how well do these emerging academic trends and innovations comport with the profession's demands? Second, to what extent and in what ways should and will law schools of the future teach the practical skills that entrylevel transactional lawyers need?

A few words about the brief history of the transactional skills curriculum will help set the stage for the discussion that follows. According to Prof. Tina Stark, a pioneer and constant advocate for transactional training, it was not until the 1990s that distinct skills training for business lawyers began to attract significant interest. ${ }^{183}$ In those early days, much of the attention was on drafting contracts. ${ }^{184}$ Later, a few law firm training professionals and continuing legal education leaders began to develop programs for teaching a broader range of transactional skills to new lawyers. ${ }^{185}$ These educators were among the first to distinguish how the process of imparting transactional knowledge and skills to developing lawyers differs from the traditional methods used to train litigators. ${ }^{186}$ Organized conferences to exchange ideas and explore skills-oriented techniques for transactional work have gained credibility just within the past ten years. In response, a few law schools started to introduce comprehensive skills programs to expand the traditional business curriculum. ${ }^{187}$ In 2011, proponents of transactional skills training gained broader endorsement from the academy when the Association of American Law Schools approved the creation of a new Transactional Law and Skills Section. ${ }^{188}$ It is against this background that the contemporary symposia and programs described below emerged.

Several recent law school conferences and symposia have inquired broadly into the future of legal education. While these programs inevitably note some transactional skills developments, their primary value for purposes of this Article is that they place transactional skills training into a much larger context. In particular, these discussions illustrate the competing propositions that account for a three-fold tension within the academic side of the legal education reform movement. One segment of the law school community defends traditional legal education, although it generally remains open to innovations of limited scope. Another embraces more sweeping reform, but promotes the primacy of

\footnotetext{
${ }^{183}$ The account in this paragraph is based on the author's personal correspondence and conversations with Prof. Stark conducted during January and March, 2012. Prof. Stark deserves special thanks not only for generously sharing her knowledge of this history, but also for her commitment to the cause of teaching transactional skills. See See Stark, supra note 125.

${ }^{184}$ See infra notes 263-266 (citing articles that reflect and derive from the relatively early interest in teaching contract drafting).

${ }^{185}$ See, e.g., Tina L. Stark, Training Junior Transactional Associates—First and Second Years, 17 ABAALI INSIDER No. 1, at 1 (Winter/Spring 2003); Stark, supra note 120, at 1.

${ }^{186}$ See Stark, supra note 125 , at 223-28.

${ }^{187}$ See Penland, supra note 5, at 118.

${ }^{188}$ See Gordon Smith, AALS Section on Transactional Law and Skills, THE CONGLOMERATE (Jun. 13, 2011), http://www.theconglomerate.org/2011/06/aals-section-on-transactional-law-and-skills.html.
} 
Teaching Transactional Skills in Partnership with the Bar

objectives other than teaching practical skills. Finally, a considerable group of law professors now enthusiastically advocate practical skills training, albeit not always in ways distinctly intended to prepare students for transactional work.

One of the most wide-ranging and innovative academic explorations of legal education reform ideas derives from the year-long Future Ed project jointly sponsored by The Harvard Law School and the New York Law School. ${ }^{189}$ In three separate conferences held over a twelve-month period beginning in the spring of 2010, many respected legal scholars met with prominent practicing lawyers, business leaders, and representatives of the legal professional development and consulting communities. The first conference looked into the current problems and challenges of legal education, considered alternative models of reform, and encouraged the participants to develop specific proposals to present at the second conference. At the second and third conferences, the participants presented, discussed, and eventually evaluated many reform proposals. Although the Future Ed project did not produce a single, contemporaneous compilation of published papers, the two schools have made the presentations and proposals available online. ${ }^{190}$

Future Ed speakers repeatedly identified the practical skills gap as one of the most pressing deficiencies of legal education. ${ }^{191}$ Most famously, during the opening panel discussion of the first Future Ed conference, Chester Paul Beach, Associate General Counsel of United Technologies Corporation, explained that his company will not pay outside counsel for the work of first or second-year associates without special approval "because they are worthless." ${ }^{\text {"192 }}$ Other par-

${ }^{189}$ See Karen Sloan, Consensus Emerging that Law School Model "Is Not Sustainable”, NAT’L L.J., Oct. 20, 2010.

${ }^{190}$ Information about the project, along with copies of written materials and video recordings of the sessions are available at http://www.nyls.edu/centers/harlan_scholar_centers/institute_for_information _law_and_policy/events/future_ed and_http://www.law.harvard.edu/programs/plp/pages/future_ed_conference.php.

${ }^{191}$ The topic received considerable attention throughout the series of three conferences but, because the Future Ed format encouraged conference participants to build on their ideas from one meeting to the next, the most fully vetted discussions appear in proposals presented at the final conference, which was held on April 15-16, 2011. These concise proposals may be downloaded at http://www.nyls.edu /centers/harlan_scholar_centers/institute_for_information_law_and_policy/events/future_ed/fe3_propos als. The proposals that mention or address the practical skills gap most directly include the following: Karen Barton, John Garvey, \& Paul Maharg, Standardized Clients and SIMPLE (SIMulated Professional Learning Environment): Learning Professionalism Through Simulated Practice; Michael Kelly, Teaching Decision-making in Law Schools: Promotion of Experimentation; Collection, Analysis and Dissemination of Materials; Creation of an Organization to Encourage Decision-Making Pedagogy in Law School Curricula; Rachel Littman \& Christine Mooney, Training New Lawyers: Post-Graduate Partnerships between Law Schools and the Legal Profession; James Moliterno, Washington \& Lee's Experiential Third Year Description and Implementation; Lori Shaw, Henry C. Strickland, \& Howard Walthall, Sr., Learning Outcomes, Practicing Lawyers, and the Berkeley Effective Lawyering Predictors; Tina L. Stark \& Eric C. Chaffee, Proposal-A Transactional Skills Curriculum for a New Century: The Need to Incorporate Practical Business and Transactional Skills Training into the Curricula of America's Law Schools; David Wilkins, Cory Way, \& Scott Westfahl, "Cradle to Grave” Legal Professional Development. Id.

${ }^{192}$ Chester Paul Beach, Assoc. Gen. Counsel of United Technologies Corp., Remarks at the New York 
ticipants also confirmed that commercial and business lawyers and their clients are especially critical of the meager practical abilities of newly admitted lawyers. ${ }^{193}$ But only one presentation and proposal during the series of conferences dealt in-depth with the transactional skills gap. ${ }^{194}$

The Future Ed presentations and proposals help put concerns over practical skills training in a proper context. The conference participants identified a plethora of other challenges and needs that law schools might address along with the skills gap. Proposals presented at the final conference argued that many alternative issues and objectives should have priority in the battle over scarce resources for revitalizing legal education. There were old standbys, such as enhanced attention to professionalism and alternative law school admission processes, and also novel innovations involving technology, globalism, and learning outcomes. ${ }^{195}$ While law schools could implement many of these pro-

Law School Future of Education Conference (Apr. 9, 2010), available at http://nyls.mediasite.com/ mediasite/SilverlightPlayer/Default.aspx?peid=11c4b60a82cc4af6a5dad0bdc29c2e9e1d. Mr. Beach's statement continued to attract attention after the Future Ed conference. See Clark D. Cunningham, Should American Law Schools Continue to Graduate Lawyers Whom Clients Consider Worthless?, 70 MD. L. REV. 499, 499 (2011).

${ }^{193}$ See, e.g., Lisa Kloppenberg, James Durham, Eric Chaffee, \& Lori Shaw, A Time of Transition: The Need for Capstone Courses in American Legal Education (Oct. 1, 2010) (proposal at the New York Law School and Harvard Law School FutureEd Conference Series), available at http://www.nyls.edu/ user_files/1/3/4/30/58/1053/Kloppenberg\&Durham\&Chaffee\&Shaw.pdf; Laura Stein, General Counsel of Clorox Corp., Keynote Address at the New York Law School and Harvard Law School FutureEd Conference Series: Proposals for Reform (Oct. 26, 2010), available at http://www.law.harvard.edu /programs/plp/pages/future_ed_conference.php; David Wilkins, Cory Way, \& Scott Westfahl, "Cradle to Grave” Legal Professional Development (Apr. 15, 2010) (proposal at the New York Law School and Harvard Law School Future Ed Conference Series), available at http://www.nyls.edu/user_files /1/3/4/30/58/1053/Wilkins_and_Way\%28final\%29.pdf.

${ }^{194}$ See Stark \& Chaffee, supra note 191.

195 The specific topics listed at the Future Ed 3 website include: teaching professionalism; developing technology solutions to facilitate collaboration among law schools and practicing lawyers across the globe; examining a major lawsuit in depth from beginning to final resolution; creating online games to teach students almost anything conventionally taught in law school, from substantive law, to decisionmaking, to skills development; involving law schools in partnerships with local lawyers and bar organizations to help new lawyers improve basic writing skills; converting the third-year of law school to an experiential learning model; improving the law school admissions process; studying the efficacy of alternative distance learning methods for law school courses; teaching legal knowledge management through online courses; developing learning outcomes with the help of local bar input; creating courses in which students develop software applications for legal work; and instituting life-long learning collaborations between law schools, legal employers, and clients. Proposals, FUTURE ED 3 CONFERENCE (NY Law School, Apr. 15-16, 2011), http://www.nyls.edu/centers/harlan_scholar_centers/institute_for_ information_law_and_policy/events/future_ed/fe3_proposals. The specific proposals involved were: Karen Barton, John Garvey \& Paul Maharg, Standardized Clients and SIMPLE (SIMulated Professional Learning Environment): Learning Professionalism Through Simulated Practice; Michele Destefano Beardslee \& Michael Bossone, Law Without Walls: Innovating Legal Education and Practice; Dennis Greene, Anatomy of a Controversy: The Study of a Major Lawsuit from Complaint to Resolution; David R. Johnson \& Tanina Rostain, Seriously Gamifying Legal Learning; Rachel Littman \& Christine Mooney, Training New Lawyers: Post-Graduate Partnerships Between Law Schools and the Legal Profession; James Moliterno, Washington \& Lee's Experiential Third Year Description and Implementation; David Oppenheimer, Predictors for Successful Lawyering: Rethinking Law School Admissions; Rebecca Purdom \& Larry Farmer, Assessing Distance Learning Methods and Success in the Law School Setting; Tanina Rostain, David R. Johnson \& Paul Lippe, Knowledge Management in Legal PracticeVirtual Externship; Lori Shaw, Henry C. (“Corky”) Strickland \& Howard P. Walthall, Learning Out- 
Teaching Transactional Skills in Partnership with the Bar

posals in ways that would help prepare students for transactional practice, as already noted, only one of them directly targeted transactional skills. ${ }^{196}$

The Future Ed agenda featured a contest of ideas in which the conference attendees awarded fictional financial support to the reform proposals judged to be most worthy. At least two of the top five proposals focused on practical skills training. ${ }^{197}$ One was based on Washington and Lee's new experiential third-year curriculum, ${ }^{198}$ and the other derived from the Daniel Webster Scholar Honors Program at the University of New Hampshire School of Law. ${ }^{199}$ Neither of these two innovations primarily addresses transactional skills, although the Washington and Lee program requires each student to take an intensive, two-week transactional practice course. ${ }^{200}$ The remaining winning proposals recommended distance learning and computer-based teaching techniques that could be applied to many different pedagogic purposes, including skills advancement. ${ }^{201}$ The sole proposal that targeted transactional skills channeled Emory Law School's transactional certificate program. ${ }^{202}$ That proposal did not finish in the top five.

While any one presentation at the Future Ed conference may contain the seeds of revolutionary change for legal education, the conference's main contribution to the questions raised in this Article derive from the scope and interrelatedness of the presentations and proposals considered collectively. Taken as a whole, these ideas correspond well with the persistent themes that also run through the recommendations voiced by the profession, as discussed in Part I of this Article. Most fundamentally, the skills gap, and the corresponding need for law schools to identify and address core competencies, figured importantly among the recurring themes, even though they did not dominate. Perhaps the most prominent common themes involve the importance of teaching problem-

comes, Practicing Lawyers, and the Berkeley Effective Lawyering Predictors Overlaying the Berkeley Study with Local Practice Community Perspectives; Tina L. Stark \& Eric C. Chaffee, Proposal - A Transactional Skills Curriculum for a New Century: The Need to Incorporate Practical Business and Transactional Skills Training into the Curricula of America's Law Schools; Brian Donnelly et al., Apps for Justice Learning Law by Creating Software; David Wilkins et al., Cradle to Grave, Legal Professional Development. Id.

${ }^{196}$ This is the proposal by Professors Stark and Chaffee referred to earlier in supra note 191 and accompanying text to note 194. It is discussed more fully later in the text. See infra notes 236-239 and accompanying text.

${ }^{197}$ The winning proposals were announced at the end of the concluding session of Future Ed 3. To watch a recording of the Future Ed 3 sessions, see http://nyls.mediasite.com/mediasite/Catalog/pages /catalog.aspx?catalogId=14aedcab-22c8-4e59-ad09-7f2169a918ee.

${ }^{198}$ See Moliterno, supra note 195.

${ }^{199}$ See Barton et al., supra note 195.

${ }^{200}$ See Moliterno, supra note 195, at 6.

${ }^{201}$ Rebecca Purdom \& Larry Farmer, Assessing Distance Learning Methods and Success in the Law School Setting; David R. Johnson \& Tanina Rostain, Seriously Gamifying Legal Learning (computerbased techniques); Ron Staudt \& Marc Lauritsen, Apps for Justice: Learning Law by Creating Software (computer-based techniques). See Proposals, supra note 195.

${ }^{202}$ See Stark \& Chaffee, supra note 191. 
solving and teamwork skills to law students, and the potential for legal education to benefit from partnerships with the practicing bar and other segments of the legal profession. Another proposition sometimes linked to all of these themes is that the interests and needs of clients must be brought more to the forefront in legal education. An additional common theme recognizes that the manner in which a particular law school should address any one reform objective, or any possible combination of innovations, must depend to a considerable extent on the school's individual teaching mission, the composition of its student body, and the characteristics of the legal community or communities in which large numbers of its graduates practice. The result of all of these considerations is that effective reform in legal education must be variable and flexible- a conclusion that complicates every reform discussion at the national level.

The Future Ed conference also highlights one of the most important distinctions affecting legal education reform. This involves a widely-held academic perspective that does not permeate the legal profession. In the debates filtering through the community of law professors and law school administrators, many challenges and objectives compete with the practical skills movement for the limited resources available to support significant changes. The leading contenders for programs, faculty, and money include globalization, reducing the cost of legal education, accreditation and lawyer licensing issues, how technology can recreate legal education, the needs and interests of theoretical legal scholars, evolving admissions standards, concerns over access to justice, and how best to serve the social justice missions central to many law schools and programs. While several of these may be significant to those advocating for skills training within the academy, none of them necessarily promises substantial attention to the skills gap and fewer still command the attention of the profession.

The Future Ed series is not the only recent academic project taking a panoramic view of legal education reform. A thought-provoking symposium on the legal academy and the practice of law, sponsored by the Maryland Law Review, is remarkable not only for its breadth and innovative ideas, but also for what it does not say about the practical skills gap. ${ }^{203}$ In more than 200 pages of commentary about recent changes affecting legal education and the profession, the symposium's participants-and most notably the law professors-wrote surprisingly little about whether or how law schools should take to heart the central criticism being leveled by the profession that legal education fails to

${ }^{203}$ See Symposium, The Profession and the Academy: Addressing Major Changes in Law Practice, 70 MD. L. REV. 307 (2011). This is no criticism of the symposium, which sought to explore actual developments in the practice of law and legal education without any predetermined focus on practical skills. The surprise is in the truth reflected by the absence of a distinct intersection of practical skills focus in those two related paths. 
Teaching Transactional Skills in Partnership with the Bar

prepare students for practice. There is in this observation no slight to the ideas presented at the symposium, but merely additional evidence that legal education reform involves significant academic, scholarly, institutional, and policy considerations that go far beyond the efficacy of a legal education for preparing lawyers to practice.

Several of the Maryland symposium papers recognize and reinforce the skills gap perception. ${ }^{204}$ And some offer insightful and original analyses of the causes and possible effects of the problem. ${ }^{205}$ But, on the whole, the symposium materials suggest that the legal academy and practicing lawyers sometimes draw entirely different conclusions from their observations of the same phenomenon. Moreover, the symposium offers little assurance that the academy will introduce revolutionary curricular reforms to teach the skills that entrylevel lawyers need. ${ }^{206}$ In fact, the concluding article in the symposium issue tenders a markedly conservative view about the changes that can occur and that are already occurring in the nation's law schools. The reform movement will, the author opines, "build incrementally" and "preserve the Socratic method as an important teaching tool while adding a number of new pedagogical tools."207 Another article in the symposium, by Professor Reynolds, roundly defends the theoretical and analytical methods of a traditional legal education that have succeeded for so long to "train students in the basic concepts that underlie vast areas of our law." 208 He concludes that the proposed reforms "cannot all be accommodated within a three-year curriculum."209

On one important point, however, aspects of the Maryland symposium converge with a consistent theme from the bar and professional development conferences discussed in Part I: law students need to learn problem-solving skills, and law schools can do more to address that need. Papers in the symposium confirm that practicing lawyers and academics agree on this. ${ }^{210}$ Even a tradi-

${ }^{204}$ See Clark D. Cunningham, Should American Law Schools Continue to Graduate Lawyers Whom Clients Consider Worthless?, 70 MD. L. REV. 499, 499-501, 504-06 (2011); Dilloff, supra note 97, at 348, 355; William D. Henderson, Three Generations of U.S. Lawyers: Generalists, Specialists, Project Managers, 70 MD. L. REV. 373, 387 (2011).

${ }^{205}$ See, e.g., Henderson, supra note 168, at 380-89 (perceiving a shift in the practice of law toward project management skills); Claire Zillman, Law Firm Leaders Survey 2010: The New Normal, AM. LAW., Dec. 3, 2010, at 68 (reporting on a recent survey of law firm leaders, in which "nearly 47 percent of respondents said that clients have refused to pay for work done by first- or second-year associates" and noting that this refusal was a "part of clients' strategy to shift economic risk back to law firms").

${ }^{206}$ See generally Michael Millemann, The Symposium on the Profession and the Academy: Concluding Thoughts, 70 MD. L. REV. 513, 519-24 (2011) (offering an overview of the symposium that considers the extent to which the traditional law school format can accommodate the extensive reforms discussed during the symposium and concluding that certain incremental changes "can be integrated into or added modestly to" the existing curriculum).

${ }^{207}$ Id. at 524.

${ }^{208}$ Reynolds, supra note 9, at 454 .

${ }^{209}$ Id. at 452.

${ }^{210}$ Dilloff, supra note 97, at 342 (stating a practitioner's view); Gillian K. Hadfield, Equipping the Garage Guys in Law, 70 MD. L. REV. 484, 484-86, 488-98 (2011) (giving a law professor's perspective); 
tionalist can endorse this proposition. Professor Reynolds, in the same article that ably expounds the virtues of a traditional legal education, notes that law professors must help students develop problem-solving skills because one of the most common and important functions of a practicing lawyer is to help clients solve legal problems. ${ }^{211}$ He argues that the usual courses and methods, when deftly executed, are well-suited to teach students how to solve legal problems. ${ }^{212}$ And he cautions reformers to "begin with preserving what has worked so well."213 Symposium participants who advocate reforms also put problem solving high on their lists of abilities that law schools can and should teach, but they differ with Professor Reynolds by questioning the effectiveness of current law school methods and programs for teaching the problem-solving skills that practicing lawyers need. ${ }^{214}$

Another article in the Maryland symposium issue demonstrates that contemporary legal education is experimenting with new ways to prepare students for practice. The article describes the Daniel Webster Scholar Program at the University of New Hampshire School of Law. ${ }^{215}$ Professor Cunningham begins the article by noting that the U.S. system is nearly unique among commonlaw jurisdictions "in not requiring rigorous practice preparation between the law degree and bar admission." ${ }^{216}$ The Webster Program seeks to mollify that distinction to some extent through a two-year experiential curriculum made available to a limited number of qualified students. ${ }^{217}$ Under the rules of the New Hampshire Supreme Court, law students who successfully complete the special honors program during their second and third years of law school may be admitted to the bar without taking a traditional bar examination. ${ }^{218}$

Professor Cunningham compares the New Hampshire experiment favorably to systems that condition bar admission on intense practice apprenticeships. ${ }^{219}$ The program sets ambitious objectives for learning outcomes, including the development of discrete practical skills intended to make students competent for practice upon graduation. The curriculum includes intense pretrial and trial ad-

Millemann, supra note 206, at 520-21 (concluding that feasible reform proposals include those calling for more problem-solving simulations, transactional problem exercises, and interdisciplinary decision making opportunities); Rhee, supra note 6, at 329-30, 334-35 (offering another academic view).

${ }^{211}$ Reynolds, supra note 9, at 453.

${ }^{212}$ Id. at $458-59$.

${ }^{213} \mathrm{Id}$. at 453.

${ }^{214}$ See supra note 210 and accompanying text. Empirical research also identifies the ability to solve problems as one of the leading characteristics of skilled lawyers. See Marjorie M. Shultz \& Sheldon Zedeck, Final Report-Identification, Development and Validation of Predictors for Successful Lawyering, Jan. 20, 2009, available at http://papers.ssrn.com/sol3/papers.cfm?abstract_id=1353554.

${ }^{215}$ Cunningham, supra note 204, at 506-12.

${ }^{216} I d$. at 504.

${ }^{217} \mathrm{Id}$. at 508 (The program began in 2006 with fifteen students, and later expanded to twenty; the law school hopes to offer the program "to all qualified applicants as soon as possible.”).

${ }^{218} I d$. at 506.

${ }^{219} \mathrm{Id}$. 
Teaching Transactional Skills in Partnership with the Bar

vocacy simulations, a negotiations seminar with a business and intellectual property emphasis, another intense simulation focused on business organizations and transactions, shorter "modules" on specialty practice areas, and written reflection papers. ${ }^{220} \mathrm{~A}$ capstone course presents students with "a variety of factual situations involving multiple areas of substantive law" to expose students to the dynamics of the attorney-client relationship in order to "hone the students' listening and counseling skills." ${ }^{221}$ The students also must take several courses that are electives for other students, and they complete at least six hours of clinics or externships and twelve hours of pro bono work. ${ }^{222}$

The state Board of Bar Examiners bases its licensing decision on a review of portfolios that the students prepare as they progress through the program. ${ }^{223}$ Although anecdotal evidence suggests that the program may be more successful than the standard curriculum in preparing students for practice, Professor Cunningham provides no objective data to show whether it achieves its defined learning outcomes. ${ }^{224}$

Other papers in the Maryland symposium deal with an important reason for law schools to be chary of the skills gap criticism. Much of the contemporary commentary on legal education comes from or on behalf of lawyers practicing in the nation's largest law firms, which employ only a minority of law school graduates. ${ }^{225}$ Some symposium participants considered the alternative perspectives of solo practitioners and lawyers who practice in small firms or those engaged in practices rarely reflected in large firms. ${ }^{226}$ These articles question the universality of the large firm critique of legal education. Similar skepticism from other quarters seasons the contemporary literature on legal education. ${ }^{227}$ These commentators remind legal educators and regulators that, even if law schools should do a much better job preparing students for practice, the skills that entry-level lawyers need in large law firms may not be the same ones that the majority of law school graduates need.

Altogether, the papers that comprise the Maryland symposium issue present a clear picture of a wide swath of the legal education reform dialogue. When viewed in the context of other surveys of the directions that law schools are moving, they help show that the academy is taking a thoughtful look at what

\footnotetext{
${ }^{220}$ Cunningham, supra note 204, at 508-09.

${ }^{221} I d$. at 509 .

${ }^{222} \mathrm{Id}$.

${ }^{223} \mathrm{Id}$. at 510 .

${ }^{224}$ See id. at $510-12$.

${ }^{225}$ See Millemann, supra note 206, at 513-15.

${ }^{226}$ See Ward B. Coe, Profound “Nonchanges” in Small and Midsize Firms, 70 MD. L. REV. 364 (2011); William Hornsby, Challenging the Academy to a Dual (Perspective): The Need to Embrace Lawyering for Personal Legal Services, 70 MD. L. REV. 420 (2011); Reynolds, supra note 9, at 452-53.

${ }^{227}$ See, e.g., Cynthia E. Nance, The Value of a Law Degree, 96 IowA. L. REV. 1629, 1640-44 (2011); Shaw, Strickland \& Walthall, supra note 191, at 3-10
} 
law schools do well, what they might do better, and what viable paths are available for improvement. They also confirm that the practical skills gap is not the center of the reform movement universe.

The Iowa Law Review also sponsored a recent symposium, The Future of Legal Education, that broadly addressed directions in legal education. ${ }^{228}$ The Iowa symposium reconfirms many of the salient features of the legal education reform movement already presented in this Article. Speakers considered the extent to which contemporary legal education should strive to produce graduates who are more ready to practice, and they debated how best to achieve that outcome. $^{229}$ And, much like the Future Ed and Maryland conferences, the Iowa symposium demonstrates that law schools face critical challenges that go well beyond the practical skills gap. For example, participants in the symposium considered the value of a legal education both as an economic investment by students and as a social and intellectual matter. ${ }^{230}$ Others addressed questions of diversity in legal education. ${ }^{231}$ And others focused on the evolving regulatory environment within which law schools operate. ${ }^{232}$ Speakers also discussed the need for law schools to attend to the important roles they play in scholarly research and higher education and in society at large. ${ }^{233}$ And some who recommended reforms also emphasized that much in traditional legal education serves the profession and the public well and should be preserved. ${ }^{234}$

Overall, the Iowa symposium gave less attention to the skills gap than some of the other recent conferences on legal education, but the published papers reflect much the same range of diverse concerns and visions evidenced by the Future Ed series and the Maryland symposium. Beyond that, the articles in the Iowa symposium underscore the number and variety of alternative and sometimes competing models of legal education reform that are in play, only some of which primarily address practical skills development. ${ }^{235}$ An important les-

${ }^{228}$ See Gail B. Agrawal, Foreward, 96 IowA. L. REV. 1449 (2011).

${ }^{229}$ See Joel W. Barrows, On Becoming a Lawyer, 96 IOWA. L. REV. 1511 (2011); Erwin Chemerinsky, Keynote Speech: Reimagining Law Schools?, 96 IowA. L. REv. 1461 (2011); Larry E. Ribstein, Practicing Theory: Legal Education for the Twenty-First Century, 96 IOWA. L. REV. 1649 (2011); Deanell Reece Tacha, Training the Whole Lawyer, 96 IowA. L. REV. 1699 (2011).

${ }^{230}$ See Richard A. Matasar, The Viability of the Law Degree: Cost, Value, and Intrinsic Worth, 96 IowA. L. REV. 1579 (2011); Nance, supra note 227.

${ }^{231}$ Kevin R. Johnson, The Importance of Student and Faculty Diversity in Law Schools: One Dean's Perspective, 96 IowA. L. REV. 1549 (2011); Catherine E. Smith, Seven Principles: Increasing Access to Law School Among Students of Color, 96 IowA. L. ReV. 1677 (2011); Kellye Y. Testy, Best Practices for Hiring and Retaining a Diverse Law Faculty, 96 IowA. L. REv. 1707 (2011).

${ }^{232}$ Judith Areen, Accreditation Reconsidered, 96 IowA. L. ReV. 1571 (2011); Jay Conison, The Architecture of Accreditation, 96 IowA. L. Rev. 1515 (2001); Michael A. Fitts, What Will Our Future Look Like and How Will We Respond?, 96 IowA. L. REV. 1539 (2011).

${ }^{233}$ See Nance, supra note 227, at 1630-32; Tacha, supra note 229, at 1705-06.

${ }^{234}$ See Fitts, supra note 232, at 1540; Ribstein, supra note 229, at 1673; Tacha, supra note 229, at 16991701.

${ }^{235}$ Some believe that skills courses are beneficial because they prepare students for the responsibilities of young attorneys. Others worry that focusing too much on technically based skills courses may come 
Teaching Transactional Skills in Partnership with the Bar

son is that while considerable evidence suggests some significant changes are coming in legal education, several competing factors complicate and restrain the reform movement.

Aside from these sweeping scholarly compilations, some isolated segments of the legal academy have considered practical skills training for transactional work in particular. Although this component of the legal education reform movement is small and underdeveloped in comparison to its well-established trial advocacy and dispute resolution counterpart, it offers the best indication of the ways in which law schools might respond to the demand for graduates who are more prepared for transactional practice.

Emory Law School's Center for Transactional Law and Practice offers particularly useful examples of how contemporary legal education is evolving to address the transactional skills gap. The Center describes its certificate program as an integrated curriculum that combines classes in doctrinal subjects with business courses and transactional skills training. ${ }^{236}$ The doctrinal topics include the law school courses one would expect, such as business organizations, taxation, and corporate finance. ${ }^{237}$ The business courses cover accounting concepts and financial analysis. ${ }^{238}$ In the skills arena, the program boasts of an integrated series that begins with contract drafting, continues with a course called Deal Skills, and culminates with a capstone experience in the form of a simulation course intended to allow the students to perform the kinds of activities that commercial law firms commonly assign to entry-level transactional attorneys. ${ }^{239}$ At least from the publically available information, it seems that the certificate program is designed to respond directly to some of the most important aspects of the transactional skills gap as described by the reports, conferences, and practicing lawyers discussed in Part I.

The Emory Center also sponsored conferences in 2008 and 2010. These sessions provide convincing evidence that many law schools and law professors around the country understand the demand for more effective transactional training and are responding with creative courses and programs. The papers from these two conferences show that much transactional skills training focuses on drafting contracts and other business documents. ${ }^{240}$ This is understandable

at the expense of traditional classes that promote the intellectual growth of students. See, e.g., Agrawal, supra note 224 , at $1451-1452$.

${ }^{236}$ Stark \& Chaffee, supra note 191, at 3-4.

${ }^{237} \mathrm{Id}$. at 3.

${ }^{238}$ See id. at 3. Centers \& Clinics: Description of the Certificate Program Curriculum, EMORY UNIV. SCHOOL OF LAW, http://www.law.emory.edu/centers-clinics/center-for-transactional-law-practice /certificate-program.html (last visited March 15, 2012).

${ }^{239}$ Stark \& Chaffee, supra note 191, at 3-4.

${ }^{240}$ See, e.g., Scott Burnham et al., Transactional Skills Training: Contract Drafting-Beyond the Basics, 2009 Transactions: Tenn. J. Bus. L. 253 (2009); Shelley Dunck et al., Teaching Contract Drafting Using Real Contracts, 12 TRAnsaCtions: TenN. J. Bus. L. 359 (2011); Grace Hum et al., Legal Writing Professors Morphing into Contract Drafting Professors, 12 Transactions: TenN. J. Bus. L. 127 
because it comports with the long-standing recognition among legal educators and lawyers that effective writing skills are critical for all fields of practice. ${ }^{241}$ Some papers from the Emory conferences propose courses and techniques to teach skills required in particular specialty areas. These include interdisciplinary approaches in which law faculty and faculty from other areas bring students from their respective fields together to solve business problems. ${ }^{242}$ Professors also offer courses on business negotiations and ethical considerations for transactional lawyers. ${ }^{243}$ A transactional curriculum could also help students gain experience in performing some of the more particular lawyering tasks required in certain specialty practices, such as issuing legal opinions in business deals and conducting due diligence for mergers and acquisitions. ${ }^{244}$

Some ideas from the Emory conferences go well beyond contract drafting and other specific skills by calling for wholesale curricular reforms designed to create transactional skills programs on par with the best skills training that already exist in legal education for litigation work. ${ }^{245}$ In a fully integrated transactional curriculum, most or all students would be exposed to fundamental principles of transactional practice and, after the first year, interested students could choose a transactional practice track. ${ }^{246}$ The upper-level curriculum would assure that students study the legal doctrine for the core substantive areas of commercial practice, as well as fundamental principles of finance and business acumen. ${ }^{247}$ In addition, advanced courses could cover transferrable skills that almost all transactional lawyers need in many different contexts, such as translating a business deal into contract terms and solving legal problems to achieve business objectives. ${ }^{248}$ Finally, transactional students would take an experiential capstone course to apply what they have learned through sophisti-

(2011); Travis Dale Jones et al., How to Create Contract Drafting Exercises, 2009 TrAnSACTIONS: TENN. J. Bus. L. 127 (2009); Wayne Schiess et al., Teaching Transactional Skills in first-Year Writing Courses, 2009 TRAnSACtions: TENN. J. Bus. L. 253 (2009); Tina L. Stark \& George W. Kuney, Transactional Skills Training: Contract Drafting - the Basics, 2009 Transactions: TenN. J. Bus. L. (SPECIAL ISSUE) 253 (2009).

${ }^{241}$ See generally KeNNETH A. ADAMS, A MANUAL OF STYLE FOR CONTRACT DRAFTING xiii-xiv (2004); BRYAN A. GARNER, LEGAL WRITING IN PLAIN ENGLISH xiii-xiv (2001).

${ }^{242}$ See Eric J. Gouvin et al., Interdisciplinary Transactional Courses, 12 TransaCtions: TENN. J. Bus. L. 101 (2011); Anthony J. Luppino et al., Pedagogic Techniques: Multi-disciplinary Courses, Annotated Document Review, Collaborative Work \& Large Groups, 2009 TransACTIONS: TENN. J. BUS. L. 73, 7379 (2009).

${ }^{243}$ See Richard K Neumann, Jr. et al., Negotiations, 12 Transactions: TenN. J. Bus. L. 153 (2011); Robert Rhee et al., Ethical Issues in Business \& the Lawyer's Role, 12 TRANSACTIONS: TENN. J. BUS. L. 37 (2011).

${ }^{244}$ See Charles R. Beaudrot, Jr., Transactional Skills Training: Opinion Letters, 2009 TrANSACTIONS: TENN. J. Bus. L. 405 (2009); Douglas Godfrey et al., Transactional Skills Training: All about Due Diligence, 2009 TRANSACTIONS: TENN. J. Bus. L. 357 (2009).

${ }^{245}$ See Tina L. Stark, Conference Introduction: My Fantasy Curriculum \& Other Almost Random Thoughts, 2009 TRANSACTIONS: TENN. J. Bus. L. 3, 3-4 (2009).

${ }^{246}$ See id. at 5-10.

${ }^{247}$ See id. at 3-10.

${ }^{248}$ See id. at $10-12$. 
Teaching Transactional Skills in Partnership with the Bar

cated simulations. ${ }^{249}$ Lab components appended to doctrinal courses could also provide similar experiential learning opportunities in less time-consuming packages. ${ }^{250}$

Emory's Center for Transactional Law and Practice and Emory's transactional teaching conferences are most significant because they show beyond doubt that law schools and law professors are heeding the bar's call for more practical training for entry-level business and transactional lawyers. As already noted, other schools also have introduced notable innovations that elevate their practical skills curricula and that include significant transactional practice components. ${ }^{251}$ It is too early to know whether these courses and programs will become standard features in most law schools. But critics can no longer properly claim that legal education ignores practical training for transactional work. ${ }^{252}$

In addition to these movements toward broad-based curricular reform, an increasing number of law professors individually are teaching transactional skills courses. A review of just a few recently published discussions will provide a flavor for how these more isolated efforts fit into the legal skills reform picture.

In the introduction to the new edition of their book on commercial leases,

${ }^{249}$ Id. at 12.

250 See Illig, supra note 118 , at 17-21.

${ }^{251}$ For example, New Hampshire’s new experiential honors program includes transactional practice, and recent developments at Washington and Lee also embrace training for transactional practice. See supra notes 198-199, 215-224 and accompanying text. Northeastern University Law School offers another particularly noteworthy curriculum, which differs from those highlighted in this Article both because of the program's longevity and because of the school's primary mission. See Elaine McArdle, Follow the (Quiet) Leader, NorTHEASTERn L. MAG., Spring/Summer 2011, at 12, 13-14 (2011). For several decades, Northeastern's learn-by-doing curriculum has been placing students outside the classroom repeatedly throughout their three years of study. Id. The program incorporates a strong social justice commitment and features numerous and long-standing partnering relationships with the practicing bar, especially lawyers in not-for-profit organizations and government agencies. The Northeastern program has not traditionally given prominence to private sector transactional skills. See Future ED: New Business Models for US and Global Legal Education, NY LAW SCHOOL, Apr. 9, 2010, http:// nyls.mediasite.com/mediasite/SilverlightPlayer/Default.aspx?peid=9b58cfed2eca40178316b10a8f477a5 21d (conference webcast). This Article's focus on limited examples drawn from the most recent and highly publicized expositions on legal education reform necessarily omits mention of many other important examples of the trend toward transactional skills programs. Id.

252 True, even among advocates for transactional and business skills training, the debate continues. The keynote discussion at the 2010 Emory conference highlights this. In his remarks, Professor Gilson observed that the number of participants and attendees at the conference show how far the transactional teaching movement in general has come. "When I started worrying about training business lawyers in the early 1980s, we could have had this meeting in a closet, and there would have been extra room for refreshments.” William J. Carney, Ronald J. Gilson, \& George W. Dent, Jr., Keynote Discussion: Just What Exactly Does a Transactional Lawyer Do?, 12 TrAnsaCTIONS: TENN. J. BUS. L. 175, 176 (2011). He went on to opine that training lawyers for business practice "has become a central feature of legal education today.” Id. A few minutes later, during the same discussion, Professor Dent was less sanguine in observing "how little attention is paid to business lawyering as opposed to litigation in the law school curriculum, generally, and in the first year of study in particular." Id. at 180. The two comments about the state of legal education for business practice are not entirely at odds, however, because Gilson's comparison had reference to past times, while Dent's concerned the still extant disparity relative to training for litigators. 
for example, Professors Bogart and Hammond explain how a course on a relatively narrow specialty topic can help students develop transferrable skills that they can use in almost any transactional practice. ${ }^{253}$ They advocate "studying leasing as a key to understanding transactional practice in general." 254 They argue that lawyers who practice in different transactional specialties all need a set of fundamental skills - not taught in traditional courses - that are transferrable from one transactional practice to another. ${ }^{255}$ The drafting and negotiating skills students learn in a course that focuses on lease documents, for example, can teach "a lawyer's approach to the practice of law" that can be broadly generalized because it is "largely (but not entirely) the same regardless of the kind of transaction involved." ${ }^{256}$ To the extent the transferability proposition is true, it becomes more feasible for schools to graduate students who are better prepared to begin practice in a broad range of transactions and business contexts.

Professor Okamoto takes a similarly optimistic stand in favor of teaching transferrable transactional skills. ${ }^{257}$ In his article about the Transactional Lawyering class that he teaches, Professor Okamoto offers a compelling case for combining the learn-by-doing technique of simulation exercises with a learnfrom-demonstration approach. ${ }^{258}$ His students first try to solve simulated transactional problems on their own, but they gain their most valuable insights in a second step in which they observe experienced practitioners attack the same problem. ${ }^{259}$ An especially interesting feature of this approach is that the practitioners need not commit to the burden of balancing a demanding practice with teaching a course on their own as adjunct professors; they can simply join the class for limited periods during the exercise, at which time they are told simply to "come prepared to be yourself and do what you do best.",260 Professor Okamoto appropriately describes this highly managed and efficient classroom use of practicing lawyers as a leveraging device because it takes the greatest advantage of practicing experts with the least commitment of their time and effort. ${ }^{261}$ Other transactional skills professors use practicing lawyers in much the

253 See DANiel B. Bogart \& Celeste Hammond, Commercial LeAsing: A Transactional Primer xv-xxi (2d ed. 2011).

${ }^{254} \mathrm{Id}$. at $\mathrm{XV}$.

${ }^{255}$ Id. at xix. The distinction between courses that can help students develop skills and traditional courses is starkly stated. "Some law school courses, notably those offered in the first year, are important building blocks to an overall understanding of the law, but they are not directly useful to practice." Id.

${ }^{256} I d$. at Xvi.

${ }^{257}$ Karl S. Okamoto, Teaching Transactional Layering, 1 DREXEL L. REV. 69, 70-74 (2009).

${ }^{258} \mathrm{See}$ id. at 87-90. Simulation exercises can be used effectively even in an introductory Business Associations course. See Carol P. Goforth, Simulations and Client-Based Exercises in the Basic Course, 34 GA. L. REv. 851 (2000). Okamoto's use of expert demonstrations and techniques, however, seems best left to advanced courses with much lower student-teacher ratios.

${ }^{259}$ Okamoto, supra note 257, at 87-89.

${ }^{260} I d$. at 77.

${ }^{261} I d$. 
Teaching Transactional Skills in Partnership with the Bar

same way either to demonstrate transactional skills or to critique student simulations. ${ }^{262}$

Although the technique is no longer a recent innovation in legal education, any discussion of transactional skills training must note that many articles and books address how to teach students the special drafting skills that transactional lawyers need. ${ }^{263}$ Indeed, contract drafting courses have been much more common in most law school curricula for much longer than courses that teach other transactional skills. ${ }^{264}$ Once again, the underlying theme in contract drafting courses is that there are fundamental, transferrable skills that every transactional lawyer needs. ${ }^{265}$ The ubiquity of drafting courses corresponds to the seemingly unending criticism from the transactional bar that few law students graduate with adequate writing abilities for a business practice. ${ }^{266}$ To the extent that the criticism remains valid, it is not simply from lack of attention to the problem by law schools.

All of these innovations and ideas from the legal academy show that law schools are paying meaningful and productive attention to the transactional skills gap. They also show that some law professors and schools have developed programs and techniques that could produce systemic changes in the way legal education trains students for business and transactional practice. What is less certain is whether the transactional skills advocates have the strength, support, and perspicacity required to achieve meaningful change across a wide spectrum of the legal reform movement.

\section{The PROMISE OF EdUCATIONAL PARTNERSHIPS BETWEEN LAW SCHOOLS AND THE BAR}

In discussing litigation and dispute resolution skills training, Professor Peter Hoffman criticizes law schools for always being "on the trailing edge of preparing students for the practice of law."267 It was, for example, only after

${ }^{262}$ See, e.g., Phillip Knott, Thinking Like a Lawyer: An English Interpretation, 2009 TRANSACTIONS: TENN. J. BUS. L. 179, 182-183 (2009) (describing a simulation exercise used in the legal practice course for solicitors under the system used in England and Wales, as conducted at Nottingham Trent University Law School); Praven Kosuri et al., You Too Can Create a Simulation Exercise (or Even a Course), 2009 TRANSACTIONS: THE TENN. J. OF BUS. L. 101, 103, 108-09 (2009).

${ }^{263}$ See, e.g., PARIS, supra note 120; TINA L. STARK, DRAFTING CONTRACTS: HOW AND WHY LAWYERS Do What They Do 29 (2007); Lisa Penland, What a Transactional Lawyer Needs to Know: Identifying and Implementing Competencies for Transactional Lawyers, 5 J. Assoc. LEG. WRITING DIRECTORS 118, 125-26 (2008).

${ }^{264}$ Using drafting to teach core transactional skills has become commonplace; what is noteworthy is that professors have only recently started to offer many other approaches for teaching transactional skills. See W. David East et al., Teaching Transactional Skills and Tasks Other Than Contract Drafting, 12 TRANSACTIONS: THE TENN. J. OF BUS. L. 217 (2011).

${ }^{265}$ See Penland, supra note 263, at 122-24.

${ }^{266}$ See supra Part I.B.2; see also supra notes 240-241 and accompanying text.

${ }^{267}$ Peter Toll Hoffman, Law Schools and the Changing Face of Practice, 56 N.Y.L.S. L. REV. 203, 208 (2012). 
most legal disputes were being resolved through discovery and pre-trial motions that law schools began teaching trial advocacy, and by the time they started to devote significant attention to discovery and pretrial skills, alternative dispute resolution was moving to the forefront. ${ }^{268}$ Law schools, Professor Hoffman concludes, do not keep up with changes in the legal environment that affect what lawyers actually do. As a result, "today's students are being readied for yesterday's legal practice."269 Could this somber condemnation of the education of future litigators apply even more accurately to the way law schools train for transactional work?

The resources and data discussed in this Article demonstrate that neither the practicing bar nor the legal academy has a consistent or coherent perspective on the practical skills gap for entry-level transactional lawyers. The deficiencies in practical skills may be central and critical or they may be tangential and secondary. And even if the problem is substantial and serious, we do not know whether or how law schools can effectively address it.

Under these circumstances, legal education needs to address at least three related objectives. First, researchers need to gather and analyze much more empirical data. Second, stakeholders in legal education and the bar must advocate and support innovation and experimentation. Third, the bar and law schools must develop new ways to collaborate with each other in preparing entry-level lawyers for practice. Each of these steps is essential if educational reform is to embrace practical skills effectively. And each requires special adaptation if reform is to encompass transactional skills.

\section{A. The Need for Empirical Data}

There is no shortage of opinions about the nature and extent of the practical skills gap. But, as the reports discussed in this Article demonstrate, the opinions conflict as much as they converge. Much of the information about the nature, extent, and significance of the skills gap is anecdotal. Some qualitative studies exist in the form of testimonials and limited reports from recent graduates, lawyer professional development departments at firms, professional development and training consultants, and senior lawyers who work with entrylevel attorneys. While there are some statistical surveys, most suffer from the same limitations that apply to the data reported in Part I.B.2 of this Article. They are too limited in scope and too narrowly targeted at discrete segments of the practice. Only sound and comprehensive data will reveal the extent to which entry-level lawyers possess or lack important abilities that they should have.

\footnotetext{
${ }^{268} I d$. at 207.

${ }^{269} \mathrm{Id}$. at 208.
} 
Teaching Transactional Skills in Partnership with the Bar

The organized bar should play a leading role in sponsoring more comprehensive research to define and evaluate the practical skills gap. Research should extend to all major types and fields of practice. Researchers should investigate the opinions, experiences, and skills of recent graduates and of accomplished lawyers. And they should include corporate counsel, clients, legal aid and nonprofit lawyers, judges, administrative lawyers, bar examiners and licensing bodies, lawyer development professionals, and others who regularly observe and train entry-level lawyers. The studies should include firms, agencies, and legal service organizations of many different sizes, in all the major practice fields, in all geographic regions of the country, and in communities of different sizes and circumstances.

Universities and law schools should support social science researchers in developing and administering a variety of research protocols. Law professors and other educators should provide the analysis, assessment, and criticism that will lead to more definitive statements of the problem. Legal educators must especially articulate the plethora of objectives and programs competing for limited resources in the nation's law schools. Because transactional law has been the stepchild of legal education and of the legal academy, understanding the transactional skills gap will require carefully tailored studies and analysis. And law schools must distinctly re-evaluate the place of transactional skills in legal education.

But even the best data on the practical skills gap will not determine which reforms make the most sense. It is no longer sufficient for law schools and law professors to divide into scholarship, teaching, and skills camps. They must create meaningful forums to carry on a productive dialogue that can lead to well-defined alternative educational programs. Where appropriate, meaningful compromises must emerge to empower law schools to serve the different constituencies and stakeholders involved.

\section{B. The Need for Innovation and Experimentation}

As Part I shows, the organized bar, lawyer training and development bodies, legal educators, and practicing attorneys are all beginning to pay much more attention to the evidence and effects of the practical skills gap. The American Bar Association, ALI-ABA, NITA, NALP, the Professional Development Consortium, and the many other organizations interested in legal education should continue to sponsor conferences, raise questions, and propose solutions. Law schools should also continue to hold symposia and carry on the debate both within academia and in cooperation with the bar. In addition, law schools and individual law professors should continue to introduce, test, evaluate, and revamp courses and programs that seek to bridge the gap. Legal educators should consider all of these efforts as important experiments that merit 
additional resources and that require critical and quantifiable assessment. Perhaps the biggest flaw in the most promising innovations to date is the lack of meaningful standards and procedures to measure their results.

Legal reform aimed at producing more competent entry-level practitioners should concentrate especially on the second and third years of law school. The greatest area of consensus that exists about legal education in the United States today is probably that the first year of law school works reasonably well for the limited but critical orientation and initiation functions that it serves. ${ }^{270}$ Of course, the first-year curriculum could be improved in many ways, including by assuring that first-year courses acknowledge transactional perspectives. But the first priority should be to define new objectives for the second and third years and to develop methods and courses to achieve those objectives. Thus, while the fundamental goals of the first year curriculum will likely remain relatively uniform from one law school to another, different law schools should be substantially liberated to promote different learning outcomes for the second and third years.

The wealthiest and most elite law schools will continue to train leaders in research, scholarship, interdisciplinary endeavors, government, politics, business, and world affairs. Educational reform at these institutions may logically give minimal attention to the practical skills gap. Many students at these schools can wait to develop practical competence in the practice of law until they need those skills. Indeed, some of these students will never practice law or will do so only briefly, as low-level associates working in subordinate roles at elite law firms.

Other schools may decide that they can best prepare their students and serve their other constituents by concentrating on a relatively narrow band of practical skills training. At least a few of these may find niche opportunities in preparing students for transactional practice. Their certificate or advanced degree programs may help meet the need for entry-level expertise in limited areas of the practice.

Many more schools, however, should consider developing programs that preserve much of the theoretical emphasis of traditional legal education but that also train some or all of their students in a wide range of the general competencies that entry-level lawyers need. Based on the limited data currently available, it seems likely that this may be the wisest course for the majority because most schools must prepare their students to succeed in many different roles. Schools in this category in particular must enhance the skills curriculum for

${ }^{270}$ See Excerpts from the Transcript, A Roundtable on the Future of Lawyer Hiring, Development and Advancement, NATL'L Ass'N FOR LegAl CAREER PROF'L 2 (Dec. 14, 2009), http:// www.nalp.org/uploads/RoundtableTranscript_12_14_09.pdf. 
Teaching Transactional Skills in Partnership with the Bar

transactional practice to help their students develop the general competencies most important for transactional work.

Through its accreditation standards, the American Bar Association must play a key role in allowing and encouraging innovation and variation in legal education. Learning outcome standards can be an important tool to assure the freedom, flexibility, and accountability that law schools need to experiment responsibly. Bar admission standards and processes should also permit, support, help assess, and reward innovations in legal education. The entire profession should pay close attention to the transitional and apprenticeship experiments underway in a few jurisdictions. As with innovations in legal education, these alternative bar admissions programs should be thoroughly studied and rigorously assessed.

\section{The Need for Collaboration between the Bar and Law Schools}

For too many generations, the legal profession and the legal academy in the United States have been, at best, distant allies. At worst, they sometimes behave more like warring factions occupying overlapping territory than different branches of the same social institution. Too many law professors and practicing lawyers regard each other with suspicion or even disdain. ${ }^{271}$ As long as this dysfunctional relationship persists, any reform in legal education will have little relevance to the practice of law.

Effective collaboration between the bar and law schools is possible. But it will require unprecedented planning, management, guidance, and persistence. Who will lead?

The practicing bar-including lawyers working in all different contexts and specialty fields, judges, and professional organizations-will benefit the most from reforms that help to close the skills gap. Additionally, the bar has greater freedom than the academy does to support far-reaching innovation and experimentation because the status quo offers no personal or career advantage to practicing lawyers, judges, and the professional organizations that represent and serve them. Moreover, the judiciary and the bar serve as the regulators and gatekeepers of the profession. For these reasons, the practicing bar is best positioned to take the lead in addressing the practical skills gap problem.

But if reform is to take root in law schools, the bar must lead by finding and exploiting shared values with legal educators and by offering resources beyond the reach of most law schools. Any approach that insists that law schools radically curtail the prevailing commitment to scholarship, policy studies, interdis-

${ }^{271}$ See, e.g., Brent E. Newton, Preaching What They Don't Practice: Why Law Faculties' Preoccupation with Impractical Scholarship and Devaluation of Practical Competencies Obstruct Reform in the Legal Academy, 62 S.C. L. REV. 105, 113-39 (2010). 
ciplinary work, or other academic mainstays will almost certainly fail, as it should. Moreover, few law schools have the capacity to finance significant curricular expansion. In short, the bar must promote practical skills partnerships with law schools that will compliment rather than threaten the schools' other institutional missions.

Skills oriented educational partnerships between the practicing bar and the legal academy will require imagination, thorough planning, and attentive execution. If the goal is a national legal educational system that produces entrylevel lawyers who possess the practice skills that the bar seems to expect, it may well take a generation or longer to travel from where legal education is today to where it needs to go. Recently, many hopeful signs have appeared across the landscape indicating routes to success. While it would be presumptuous to propose a roadmap at this stage, it is possible to suggest some directions that reform might take.

The possibilities include variations in how law schools involve practicing lawyers directly in teaching, imaginative partnership opportunities for law schools and the bar, and innovative licensure requirements to facilitate the transition from law school to law practice. To illustrate how the bar and law schools might work together to address the transactional skills gap, this section concludes with a few concrete ideas about those paths to reform.

\section{Alternative ways for practicing lawyers to teach law students}

It is time to rethink the most efficacious ways to use judges and practicing lawyers in formal legal education. Ever since the academic model overcame the apprenticeship model, experienced members of the bar have been adding a practical flavor to the law school experience as valued guest speakers and adjuncts. This practice will certainly continue. But guest speakers only bring momentary value to the classroom, and relatively few experienced practitioners are also accomplished teachers. Law schools can benefit from alternative approaches that ask experienced judges and lawyers to contribute their expertise in more efficient and effective ways.

One of the most promising new techniques simply asks practitioners to display for students the skills that define professional competence. Using this alternative approach, law professors build into their courses exercises in which skilled lawyers demonstrate how to solve common problems that clients present. Professors can also ask lawyers to observe and critique student performance in practice simulations. The contrast with tradition is stark: is it better to ask experienced lawyers to aid legal education by doing what they do best or to continue to encourage them to mimic law professors by teaching from appellate 
Teaching Transactional Skills in Partnership with the Bar

opinions and conducting Socratic dialogues? $?^{272}$

One of the key advantages of this method is its efficiency. Law professors develop and conduct the courses, provide the doctrinal and fundamental instruction, assign grades, and otherwise administer the process. The practitioners need only make discrete contributions by helping professors devise realistic exercises and simulations and by attending just one or a few classes to provide demonstrations and critiques. This technique should make it more attractive for the most experienced and busiest lawyers to participate in practical skills education. And available technology will allow lawyers from anywhere to contribute to a course being taught anywhere else.

Lawyers who want to devote more time to their local law schools can take the demonstration and critique model to the next step by offering discrete laboratory components appended to doctrinal courses. Schools can offer labs on an optional basis to students who wish to go beyond knowledge of the law to develop entry-level competence in the related practice area. ${ }^{273}$

\section{Curricular reform}

Law schools should continue to experiment with skills training innovations, especially ones that partially or completely replace the third year. In developing these programs, schools should consult with their alumni and the firms and other organizations that regularly hire their graduates. Just as importantly, law schools should gather meaningful data on the outcomes that the programs achieve, and they should regularly publish analyses of those investigations. And law schools interested in teaching practice skills for business and transactional work should also collaborate more with business schools.

Large law firms can play an especially useful role in helping law schools develop practical skills programs. Through their competency models, major law firms have already developed standard training programs for entry-level lawyers in both commercial litigation and business and transactional practice. Through their management and professional development organizations, major firms should offer to work with willing law school partners to derive from these law firm training and evaluation models a core practice curriculum for law schools, an advanced skills curriculum for certificate programs and advanced degrees, and a first-year associate curriculum.

272 This model draws extensively from practices promoted by Prof Okamoto. See supra notes 257-261 and accompanying text. The approach is not, of course, a completely new notion. Law professors routinely bring experienced lawyers into their classes to model competence. Additionally, law school competitions depend extensively on practicing lawyers to judge students as they role play in law practice exercises. The difference is that the model discussed in the text is designed as a more comprehensively integrated and sustained element of the program by which law students earn academic credit toward the J.D. degree.

${ }^{273}$ See Robert C. Illig, The Oregon Method: An Alternative Model for Teaching Transactional Law, 59 J. LEGAL EDUC. 221, 234-38 (2009) (describing such lab courses at the University of Oregon). 
Firms of almost any size and practice can also work together with law schools to develop apprenticeship programs run by firms that commit to follow an agreed curriculum. ${ }^{274}$ At least three variations on this theme may be worth exploring. First, for students able to work at firms during the school term, the apprenticeship may be conceived as a hybrid program that combines attributes of an academic externship with a traditional clerkship. Working together, schools and firms should be able to address the adjustments that this approach may require to accreditation standards, compensation arrangements, and billing practices. ${ }^{275}$ Second, for many firms, apprenticeship programs might replace expensive summer associate programs. In major cities, law firms might collaborate with one another to create summer apprenticeship programs in which the firms share some practical training exercises. Even in smaller markets, schools might develop summer apprenticeship programs suitable to their local circumstances. Firms could still reserve time for the summer apprentices to work on selected client matters and to shadow senior lawyers. This structure would allow participating firms to continue to use their summer programs for recruiting purposes. Third, post-J.D. apprenticeships could provide transitional programs designed for specialty practice areas and elite law firm practice. Schools that develop post-J.D. apprenticeship programs could thereby increase tuition revenues and also enhance their relationships with participating firms. And such programs should help firms and clients by facilitating a rational structure that greatly reduces entry-level salaries and that allows firms to bill for the work of apprentice lawyers based on standard billing guidelines and client consent.

In pursing their unique role in these reforms, large law firms must recognize that they represent a minority segment of the legal services market that should pay its own way. Elite firms, for example, may need to develop sensible ways to finance summer and post-J.D. apprenticeship programs. One possible device would be for a participating firm to pay apprentice lawyers reduced salaries, but finance the cost of the associates' apprenticeships in some way, perhaps by committing to pay off educational loans over time for apprentices who continue with the firm and who meet specified productivity benchmarks.

Reform efforts should also involve lawyers and bar organizations from across the practice spectrum. National and state bar associations can play leading roles in developing general frameworks. More specialized bar groups and professional development organizations should develop legal education taskforces focused on their practice areas, similar to that established by the Real Estate Division of the American Bar Association's Real Property, Trusts and Estates Section. ${ }^{276}$ For example, for commercial practice skills, the American

\footnotetext{
${ }^{274}$ In principle, even individual lawyers, if sufficiently experienced, could take on apprentices.

${ }^{275}$ See generally Circo, supra note 175, at 119-23.

${ }^{276}$ See supra notes $24-31$ and accompanying text.
} 
Teaching Transactional Skills in Partnership with the Bar

Corporate Counsel Association could help design apprenticeship programs and related billing guidelines for firms to follow when they assign apprentice lawyers to clients' business matters. Corporate legal departments and not-forprofit organizations could also participate by taking on apprentices. Law schools, professional development organizations, and CLE providers could compete for opportunities to deliver the skills training components of apprenticeship programs. Law schools should use their boards of visitors and alumni advising groups more extensively to determine which practical skills are most in demand in each school's primary placement market and to provide a support network.

Curricular reform for transactional practice will require special attention. To help law schools develop a skills curriculum for entry-level transactional work, the bar should focus on three critical objectives that are especially difficult for law faculties to achieve. The first is identifying general skills that entry-level transactional lawyers need. Reforms should emphasize general competencies over technical ones. As already noted, existing core competencies programs being used by major law firms can help with this task. The second objective is to develop a transactional skills curriculum at every law school that suits the needs of that school's student body. For many schools, this may require state and local bar associations to initiate partnership proposals and to help schools develop funding sources. The final step requires the organized bar to work with law faculties to determine the most efficient techniques and programs for teaching transactional skills. Some of the possibilities have already been mentioned, including introducing formal apprenticeships and post-J.D. programs and using experienced lawyers to model practice skills for students, to critique student performances in simulations, and to teach laboratory supplements to traditional courses. For transactional apprenticeships and post-J.D. programs the organized bar must stimulate a discussion about whether law schools or the bar should exercise primary or exclusive responsibility.

\section{Licensing innovations}

A final question is whether, under current circumstances, the public interest requires that entry-level lawyers must have greater practical competence than students can be expected to develop solely by attending law school. Licensing rules should recognize that lawyer competence is a continuum that requires attention over a span of the applicant's early career and not merely through a single bar examination event. While individual jurisdictions could continue to address this question separately, the matter is one of national scope, and it calls for a national debate. And even though the issue necessarily extends beyond the role of formal legal education as currently understood in the United States, legal educators should participate in the dialogue. 
For some purposes, it may be sufficient to require recent law school graduates to attend greatly enhanced "bridging the gap" seminars, either as a condition to initial admission or via continuing legal education requirements over the first few years of practice. Courts of limited jurisdiction, for example, might adopt this approach to qualify law school graduates to make solo court appearances. Other aspects of the practice may require a national conversation about the need for mandatory apprenticeship programs, administered under rules adopted by the judiciary or licensing boards. Perhaps licensing rules should require every law graduate to complete an apprenticeship as a condition to being authorized to practice law except under the supervision of an experienced lawyer certified as a mentor.

\section{FINAL THOUGHTS}

Proponents of practical skills reforms should maintain a realistic perspective. For more than a century, the post-graduate, academic system of legal education has supplied this country with talented and effective advocates, counselors, scholars, and political and civic leaders. Entry-level lawyers in the United States today are broadly and highly educated and, as a result, they are wellequipped to adapt to the constantly changing demands and opportunities they can expect over their careers. The current legal education reform movement must recognize and respect these attributes of the status quo, but it should not cower in the face of resistance to change.

To assess the growing concerns about the practical skills gap in legal education, the profession and the academy need to encourage further dialogue among the many constituencies involved, and they need to support and analyze much more empirical research into the extent, causes, and significance of the problem. The public interest will best be served by innovation, flexibility, and experimentation in legal educational. No matter whether the practical skills gap evidences a crisis or a lesser shortcoming, the profession should continue to press for reforms that will better prepare law school graduates to enter the practice as minimally competent lawyers.

If the practical skills reform movement succeeds at the level that many proponents advocate, law schools may experience significant stress and trauma. But law schools will continue to thrive as academic units of universities. Most should be able to improve practical skills training without reducing their commitments to traditional scholarly agendas and institutional missions. A few schools may choose paths that are less devoted to academic values and more oriented toward practical skills training. For reform to be comprehensive and fully effective, however, the bar, bar examiners, law firms, and CLE providers 
Teaching Transactional Skills in Partnership with the Bar

must assume much of the responsibility. ${ }^{277}$ Ultimately, society will benefit most when the bar and law schools seek out educational partnerships with one another.

\footnotetext{
${ }^{277}$ See supra note 89 and accompanying text.
} 